\title{
MESMO 2: a mechanistic marine silica cycle and coupling to a simple terrestrial scheme
}

\author{
K. Matsumoto ${ }^{1}$, K. Tokos ${ }^{2}$, A. Huston ${ }^{2}$, and H. Joy-Warren ${ }^{3}$ \\ ${ }^{1}$ Department of Earth Sciences, University of Minnesota, Minneapolis, Minnesota, USA \\ ${ }^{2}$ University of California, Santa Cruz, California, USA \\ ${ }^{3}$ University of Chicago, Chicago, Illinois, USA \\ Correspondence to: K. Matsumoto (katsumi@umn.edu)
}

Received: 20 June 2012 - Published in Geosci. Model Dev. Discuss.: 24 September 2012

Revised: 7 February 2013 - Accepted: 19 March 2013 - Published: 12 April 2013

\begin{abstract}
Here we describe the second version of Minnesota Earth System Model for Ocean biogeochemistry (MESMO 2), an earth system model of intermediate complexity, which consists of a dynamical ocean, dynamicthermodynamic sea ice, and energy moisture balanced atmosphere. The new version has more realistic land ice masks and is driven by seasonal winds. A major aim in version 2 is representing the marine silica cycle mechanistically in order to investigate climate-carbon feedbacks involving diatoms, a critically important class of phytoplankton in terms of carbon export production. This is achieved in part by including iron, on which phytoplankton uptake of silicic acid depends. Also, MESMO 2 is coupled to an existing terrestrial model, which allows for the exchange of carbon, water and energy between land and the atmosphere. The coupled model, called MESMO 2E, is appropriate for more complete earth system simulations. The new version was calibrated, with the goal of preserving reasonable interior ocean ventilation and various biological production rates in the ocean and land, while simulating key features of the marine silica cycle.
\end{abstract}

\section{Introduction}

Here we document development of the second version of the Minnesota Earth System Model for Ocean biogeochemistry (MESMO 2). The first version described earlier (Matsumoto et al., 2008) is based on a non-modular version of the Grid ENabled Integrated Earth system model (GENIE; http://www.genie.ac.uk/), which in turn is based on the computationally efficient ocean-climate model of Edwards and
Marsh (2005). This work is independent of the efforts of the GENIEfy project to develop different flavors of the modularised GENIE.

MESMO has a 3-D dynamical ocean on a $36 \times 36$ equalarea grid with 16 vertical levels. It is coupled with a 2-D energy-moisture balanced model (EMBM) of the atmosphere, dynamic and thermodynamic models of sea ice, and a prognostic model of marine biogeochemistry. It is an earth system model of intermediate complexity (EMIC), a group which occupies an important and unique position within the hierarchy of climate models (Claussen et al., 2002). EMICs represent a compromise between high resolution, comprehensive coupled models of atmospheric and oceanic circulation, which require significant computational resources, and conceptual (box) models, which are computationally very efficient, but represent the climate system in a highly idealised manner. As an EMIC, MESMO retains important dynamics, which allow for simulations of transient climate change, while remaining computationally efficient. The efficiency is achieved by reducing spatial resolution as well as the number and detail of processes compared to high resolution coupled models.

Calibration of the earlier MESMO 1 benefited from multiobjective tuning of the physical model parameters, whereby the mismatch between model-simulated fields and equivalent observed fields was minimised. The equilibrium run of MESMO 1 is well calibrated with respect to oceanic uptake of anthropogenic transient tracers, chlorofluorocarbons, anthropogenic carbon, and radiocarbon (Matsumoto et al., 2008). These tracers reflect ocean ventilation over decades to a century by intermediate waters in the upper ocean as well as 


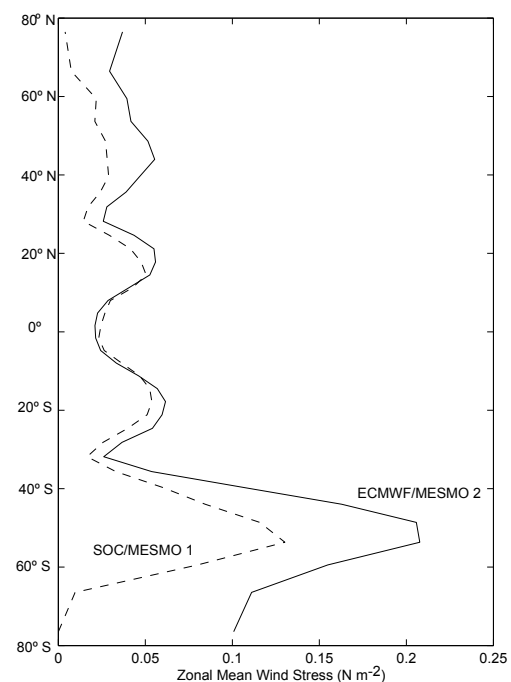

Fig. 1. Zonal mean of surface wind stress fields SOC (Josey et al., 2002) used in MESMO 1 and ECMWF (Trenberth et al., 1989) used in MESMO 2/2E.

by the relatively rapid North Atlantic Deep Water (NADW). The model is also well calibrated on centennial time scale with respect to the abundance of natural ${ }^{14} \mathrm{C}\left(\Delta^{14} \mathrm{C}\right)$ in the deep Pacific and Indian. MESMO 1 has been used successfully in a number of carbon and climate process studies (Lee et al., 2011; Matsumoto and McNeil, 2013; Matsumoto et al., 2010; Matsumoto and Yokoyama, 2013; Sun and Matsumoto, 2010; Ushie and Matsumoto, 2012) as well as in model intercomparison projects (Archer et al., 2009; Cao et al., 2009; Eby et al., 2012; Joos et al., 2012; Weaver et al., 2012; Zickfeld et al., 2012).

A strong motivation for developing MESMO 2 was to investigate the climate-carbon feedbacks involving diatoms, which were not represented in MESMO 1. Diatoms are critical in the ocean carbon cycle, because they are by far the most important agent of vertical transport of carbon from the surface to the deep ocean (Armstrong et al., 2002). Because they can very rapidly grow when conditions are favourable and form mats that facilitate fast sinking, diatoms can account for most of the carbon export production that takes place in the Southern Ocean and more than $50 \%$ globally (Sarmiento and Gruber, 2006). Diatom production is often limited by the availability of silicic acid $\left(\mathrm{Si}(\mathrm{OH})_{4}\right)$. The silicic acid limitation in much of the low latitudes has its origin in the Southern Ocean, where iron $(\mathrm{Fe})$ deficiency causes Antarctic diatoms to utilise proportionally more $\mathrm{Si}(\mathrm{OH})_{4}$ for a given amount of $\mathrm{NO}_{3}$, so that $\mathrm{Si}: \mathrm{N}$ utilisation ratio is generally elevated (Sarmiento et al., 2004). The high uptake rate of $\mathrm{Si}(\mathrm{OH})_{4}$ in the Southern Ocean causes its depletion there. With available data, it is possible to trace this depletion signal originating from the Southern Ocean and spreading to the rest of the ocean via Antarctic Intermediate and Mode Waters (Brzezinski et al., 2002; Sarmiento et al., 2004). These are key features of the observed silica cycle that we chose to simulate with MESMO 2, made possible in part by including Fe as a new tracer in the model.

Another motivation for this work is to have a model that includes a terrestrial scheme, so that the global carbon cycle encompassing the atmosphere, ocean, and land can be simulated. A terrestrial scheme with prognostic land surface albedo would also allow a land albedo feedback in global climate change simulations. In this regard, we make use of the existing model ENTS (efficient numerical terrestrial scheme), coupled previously to GENIE (Williamson et al., 2006). MESMO 2 coupled to ENTS is here referred to as MESMO 2E. In this work, the equilibrium simulations of MESMO 2 and MESMO 2E are described. Key diagnostics of their equilibrium states are summarised in Table 1.

\section{New features of MESMO 2}

In the following two sections, we describe in steps the main new physical and biogeochemical modifications and additions which were adopted in MESMO 2 (Table 2). We begin in Sect. 2.1 with improvements to the physical model. They include a more realistic local surface albedo specification and seasonal reanalysis winds products from EMCWF. In Sect. 2.2, we describe the development of the new biogeochemical model, which includes separating export production by two size classes of phytoplankton. The larger phytoplankton class represents diatoms and requires the iron and silica cycles, which are also described in this section.

\subsection{New physical features}

In MESMO 1, planetary albedo is determined as function of latitude, and ranges from 0.2 at low latitudes to 0.5 at high latitudes. Sunlight reflectivity generally increases with latitude, because sun rays strike the surface at oblique angles, must pass a greater column of atmosphere, and the ground surface more frequently has ice or snow. The planetary albedo in MEMSO determines the reflectivity at the top of the atmosphere with respect to incoming shortwave radiation and follows the original and current formulation in GENIE (Marsh et al., 2011). At the surface, local albedo is modified by the presence of sea ice and can reach a maximum value of 0.7. As there is no land model in MESMO 1, a rather unrealistic situation arises, whereby the surface albedo of the ice sheets on both Greenland and Antarctic is too low, even lower than sea ice located at lower latitudes. So in the first step of MESMO 2 development, we correct this by specifying a land mask with higher albedo (Table 2). Since this increases the global average surface albedo, the latitudinal profile of the planetary albedo is reduced uniformly by $3.5 \%$ to compensate.

The second important change made in MESMO 2 is the replacement of the annual mean wind stress field used in 
Table 1. Key model diagnostics and data constraints. Mean SST and SSS based on the 2009 World Ocean Atlas (Antonov, 2010, Locarnini, 2010). The domains of the deep water masses for calculation of $\Delta^{14} \mathrm{C}$ follow the definitions from the Ocean Carbon Cycle Model Intercomparison Project (Matsumoto et al., 2004): NADW: equator to $60^{\circ} \mathrm{N}, 1000-3500 \mathrm{~m}$; CDW: $90^{\circ} \mathrm{S}$ to $45^{\circ} \mathrm{S}, 1500-5000 \mathrm{~m}$; and NPDW: equator to $60^{\circ} \mathrm{N}, 1500-5000 \mathrm{~m}$. Note that all model results except for the 1994 tracer inventories are values at equilibrium, while most of the data constraints are from the postindustrial period. In particular, global mean surface air temperature of $14.0^{\circ} \mathrm{C}$ from Jones et al. $(1999)$ represents the $1961-1990$ period. The equivalent value is $14.2^{\circ} \mathrm{C}$ for MESMO 2 and $14.3^{\circ} \mathrm{C}$ for MESMO $2 \mathrm{E}$ for transient simulations in which the models were forced with observed atmospheric $\mathrm{pCO}_{2}$ with $\mathrm{CO}_{2}$ radiative feedback. Similarly, the polar sea ice extent for the year 2000 in the same postindustrial transient simulations is smaller by $8-10 \%$ than at the equilibrium, improving the data-model comparison than presented in the table.

\begin{tabular}{|c|c|c|c|c|c|}
\hline & Unit & Constraints & MESMO1 & MESMO2 & MESMO2E \\
\hline \multirow[t]{2}{*}{ Simulation ID\# } & & & 090309a & $120531 \mathrm{a} / \mathrm{m} / \mathrm{n}$ & $120531 \mathrm{~b} / \mathrm{x} / \mathrm{y}$ \\
\hline & & & $090415 b$ & $130124 \mathrm{a}$ & $130124 b$ \\
\hline \multicolumn{6}{|l|}{ Global physical } \\
\hline Mean surf air temp & ${ }^{\circ} \mathrm{C}$ & 14.0 & 11.4 & 13.5 & 13.6 \\
\hline Mean SST & ${ }^{\circ} \mathrm{C}$ & 18.5 & 17.6 & 18.5 & 17.4 \\
\hline Mean SSS & PSU & 34.6 & 34.7 & 34.7 & 34.4 \\
\hline Atlantic MOC & $10^{6} \mathrm{~m}^{3} \mathrm{~s}^{-1}$ & $14-27$ & 12 & 12 & 17 \\
\hline Arctic sea ice, Feb & $10^{6} \mathrm{~km}^{2}$ & $14-16$ & 21 & 20 & 18 \\
\hline Antarctic sea ice, Sept & $10^{6} \mathrm{~km}^{2}$ & $17-20$ & 34 & 33 & 26 \\
\hline NADW $\Delta^{14} \mathrm{C}$ & $\%$ & $-67 \pm 29$ & -99 & -104 & -92 \\
\hline $\mathrm{CDW} \Delta^{14} \mathrm{C}$ & $\%$ & $-155 \pm 12$ & -153 & -156 & -145 \\
\hline NPDW $\Delta^{14} \mathrm{C}$ & $\%$ & $-226 \pm 14$ & -216 & -196 & -190 \\
\hline \multicolumn{6}{|l|}{ Ocean carbon } \\
\hline POC production & $\mathrm{PgC}_{\mathrm{y}}{ }^{-1}$ & $9-13$ & 10.6 & 11.9 & 12.5 \\
\hline Opal production & Tmol-Si y $^{-1}$ & 100 & - & 130 & 139 \\
\hline $\mathrm{CaCO}_{3}$ production & $\mathrm{PgC} \mathrm{y}^{-1}$ & $<1$ & 0.9 & 1.0 & 0.9 \\
\hline \multicolumn{6}{|l|}{ Terrestrial carbon } \\
\hline Net photosynthesis & $\mathrm{PgC}^{-1}$ & 120 & - & - & 123 \\
\hline Vegetation respiration & $\mathrm{PgC}^{-1}$ & 60 & - & - & 62 \\
\hline Leaf litter/soil respiration & $\operatorname{PgC~}^{-1}$ & 60 & - & - & 61 \\
\hline Land Veg. Carbon & $\mathrm{PgC}$ & 451 & - & - & 462 \\
\hline Soil Carbon & $\mathrm{PgC}$ & 1306 & - & - & 1319 \\
\hline \multicolumn{6}{|l|}{1994 tracer inventories } \\
\hline CFC-11 & $10^{6}$ mole & $0.55 \pm 0.12$ & 0.69 & 0.56 & 0.59 \\
\hline Anthropogenic carbon & $\mathrm{PgC}$ & $118 \pm 19$ & 118 & 100 & 101 \\
\hline
\end{tabular}

MESMO 1 with seasonal wind stress fields to drive ocean dynamics (Fig. 1, Table 2). Following GENIE's core climate model (Edwards and Marsh, 2005), MESMO 1 uses the annual mean wind stress data from Southampton Oceanography Centre (SOC) climatology (Josey et al., 1998). This is replaced in MESMO 2 with the monthly mean wind stress fields from the European Centre for Medium-Range Weather Forecasts (ECMWF) reanalysis for the period 1980-1989 (Trenberth et al., 1989). As noted by Josey et al. (2002), the reanalysis winds are approximately $40 \%$ stronger over the Southern Ocean than observation-based winds such as the SOC winds (Fig. 1). As a result, the introduction of the seasonal ECMWF wind stress fields in MESMO 2 greatly strengthens its ocean ventilation, so that the deep ocean $\Delta^{14} \mathrm{C}$ becomes unrealistically young. In MESMO $1, \Delta^{14} \mathrm{C}$ of the NADW, Circumpolar Deep Water (CDW), and North Pacific Deep Water (NPDW) is respectively $-99 \%$, $-153 \%$, and $-216 \%$. These values are in good agreement with observed, natural $\Delta^{14} \mathrm{C}$ values (Table 1). The use of the ECMWF winds alone increases them to $-80 \%$ o, $-104 \%$, and $-129 \%$, respectively.

In the third step and in an effort to correct this excessive ventilation, we removed the artificial wind stress scaling factor everywhere except in the far North Atlantic. A scaling factor of about 2 was introduced originally by Edwards and Marsh (2005) to achieve sufficiently strong wind driven circulation, and that factor is carried forward in MESMO 1. Using the seasonal ECMWF winds and removing the scaling 
Table 2. Model parameters. In MESMO 1, there is only one class of phytoplankton that carries out export production and, therefore, only one half saturation constant for each limiting nutrient. In MESMO 2/2E, the half saturation constants for the large (LP) and small (SP) phytoplankton are respectively larger and smaller than the equivalent values for MESMO 1.

\begin{tabular}{|c|c|c|c|c|}
\hline & Unit & MESMO1 & MESMO2 & MESMO2E \\
\hline \multicolumn{5}{|l|}{ Physical model } \\
\hline Ice sheet albedo & & 0.5 & 0.8 & 0.8 \\
\hline Change in planetary albedo & & $0 \%$ & $-3.5 \%$ & $-5.5 \%$ \\
\hline Wind stress & & Annual NCEP & $\begin{array}{l}\text { Seasonal } \\
\text { ECMWF }\end{array}$ & $\begin{array}{l}\text { Seasonal } \\
\text { ECMWF }\end{array}$ \\
\hline Wind scaling & & 2.0 globally & 2.0 in N. Atlantic & 2.0 in N. Atlantic \\
\hline FW flux adjustment in north & $10^{6} \mathrm{~m}^{3} \mathrm{~s}^{-1}$ & 0.2 & 0.3 & 0.3 \\
\hline FW flux adjustment in south & $10^{6} \mathrm{~m}^{3} \mathrm{~s}^{-1}$ & -0.03 & -0.13 & -0.13 \\
\hline \multicolumn{5}{|l|}{ Biogeochemical model } \\
\hline LP: Optimal nutrient uptake & $\mathrm{Yr}^{-1}$ & & 0.01 & 0.01 \\
\hline SM: Optimal nutrient uptake & $\mathrm{Yr}^{-1}$ & & 0.16 & 0.16 \\
\hline $\mathrm{LP}: \mathrm{K}_{\mathrm{PO}_{4}}$ & $\mu \mathrm{mol} \mathrm{kg}-1$ & 0.2 & 0.39 & 0.39 \\
\hline SM: $\mathrm{K}_{\mathrm{PO}_{4}}$ & $\mu \mathrm{mol} \mathrm{kg}-1$ & 0.2 & 0.03 & 0.03 \\
\hline LP: $\mathrm{K}_{\mathrm{NO}_{3}}$ & $\mu \mathrm{mol} \mathrm{kg}-1$ & 3.4 & 5.00 & 5.00 \\
\hline SM: $\mathrm{K}_{\mathrm{NO}_{3}}$ & $\mu \mathrm{mol} \mathrm{kg}-1$ & 3.4 & 0.50 & 0.50 \\
\hline LP: $\mathrm{K}_{\mathrm{CO}_{2}}$ & $\mu \mathrm{mol} \mathrm{kg}-1$ & 0.5 & 0.925 & 0.925 \\
\hline SM: $\mathrm{K}_{\mathrm{CO}_{2}}$ & $\mu \mathrm{mol} \mathrm{kg}-1$ & 0.5 & 0.075 & 0.075 \\
\hline $\mathrm{LP}: \mathrm{K}_{\mathrm{Fe}}$ & $\mathrm{nmol} \mathrm{kg}-1$ & & 0.10 & 0.10 \\
\hline $\mathrm{SM}: \mathrm{K}_{\mathrm{Fe}}$ & $\mathrm{nmol} \mathrm{kg}{ }^{-1}$ & & 0.01 & 0.01 \\
\hline $\mathrm{K}_{\mathrm{Si}(\mathrm{OH}) 4}$ & $\mu \mathrm{mol} \mathrm{kg}-1$ & & 1.00 & 1.00 \\
\hline Cond. Stability, ligand-bound $\mathrm{Fe}$ & & & $1.25 \times 10^{11}$ & $1.25 \times 10^{11}$ \\
\hline Fe scavenging rate by $\mathrm{POC}$ & & & 0.7 & 0.7 \\
\hline Particle sinking speed & & $50 \mathrm{~m} \mathrm{~d}^{-1}$ & $30 \mathrm{~m} \mathrm{~d}^{-1}$ & $30 \mathrm{~m} \mathrm{~d}^{-1}$ \\
\hline Maximum Fe:C & & & 200000 & 200000 \\
\hline \multicolumn{5}{|l|}{ Terrestrial scheme ENTS } \\
\hline k18 (photosynthesis) & & - & - & 2.392 \\
\hline k24 (vegetation respiration) & & - & - & 0.172 \\
\hline k29 (soil respiration) & & - & - & 0.0725 \\
\hline
\end{tabular}

completely reduce the excessive deep ventilation significantly and improves the deep $\Delta^{14} \mathrm{C}$ distribution. However, the Atlantic meridional overturning circulation (MOC) becomes too weak ( $\left.6 \mathrm{~Sv} ; \mathrm{Sv}=10^{6} \mathrm{~m}^{3} \mathrm{~s}^{-1}\right)$. Therefore, in order to maintain the Atlantic MOC to a reasonable strength in MESMO 2, the wind scaling of 2 is kept northward of $40^{\circ} \mathrm{N}$. Also, the Atlantic-to-Pacific freshwater flux adjustment was increased from 0.2 to $0.3 \mathrm{~Sv}$ in the Northern Hemisphere, but reduced in the Southern Hemisphere by the same amount, so that the basis-wide adjustment remains unchanged. With these changes, the Atlantic MOC is $12 \mathrm{~Sv}$ in MESMO 2 and $17 \mathrm{~Sv}$ in MESMO 2E (Table 1). These freshwater flux adjustments can appear ad hoc, but they compensate for the typically weak transport of moisture in EMBM and are necessary to achieve a reasonably strong MOC in the model architecture of GENIE (Marsh et al., 2011).

In MESMO 1, the winds that drove the different components of the model were different wind products. For exam- ple, the wind stress fields that drove ocean dynamics were not consistent with the wind speed fields that drove air-sea gas exchange. And winds that drove evaporation, precipitation, and the transport of heat and moisture in the 2-D atmospheric model were different still. In version 2 , all components of the model, including the terrestrial model ENTS are now consistently driven by the same seasonal ECMWF reanalysis winds.

\subsection{New biogeochemical features}

The limiting nutrients in MESMO 1 are phosphate $\left(\mathrm{PO}_{4}\right)$, nitrate $\left(\mathrm{NO}_{3}\right)$, and aqueous $\mathrm{CO}_{2}$, whose uptake is governed by Michaelis-Menton kinetics with calibrated half saturation rates. Organic carbon production is assumed to be carried out by only one generic class of phytoplankton, and it is modelled as export production in the top two layers above the fixed compensation depth of $100 \mathrm{~m}$. In MESMO 2, Fe and 
a) MESMO1 AMOC (Sv)

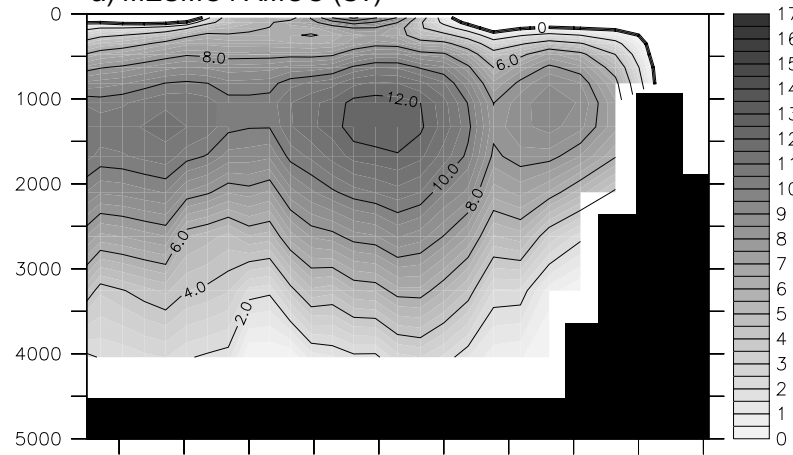

b) MESMO2 AMOC (Sv)

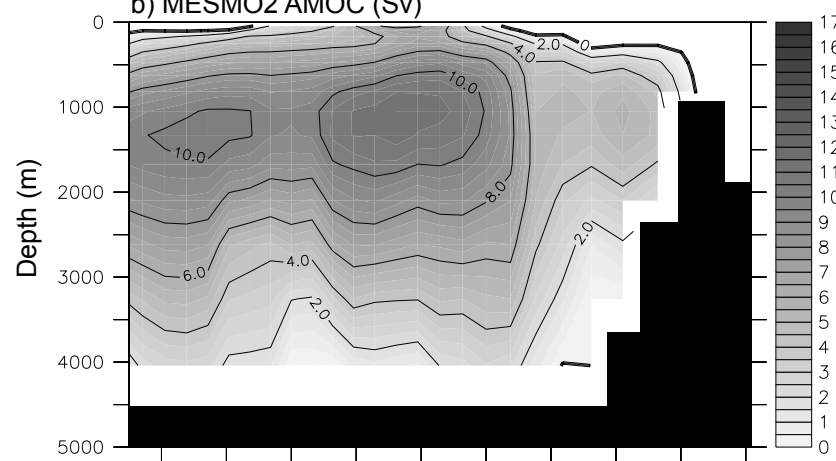

c) MESMO2E AMOC (Sv)

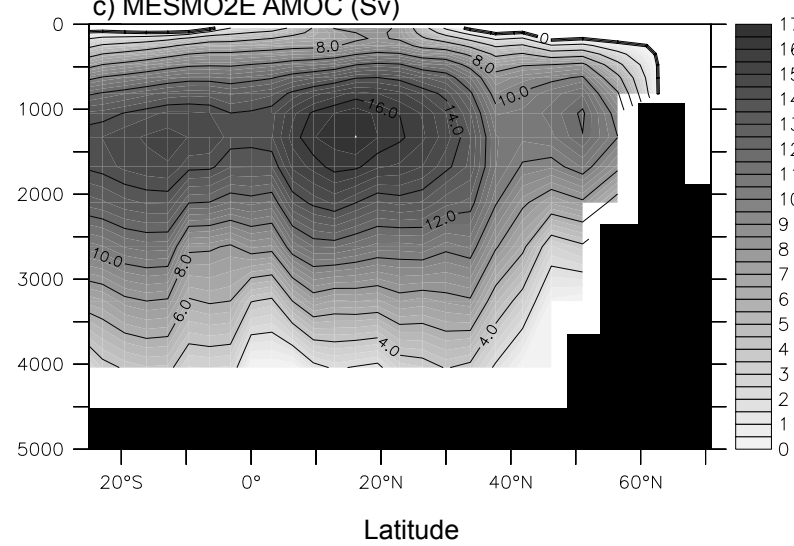

Fig. 2. The Atlantic meridional overturning circulation in three versions of MEMSO.

$\mathrm{Si}(\mathrm{OH})_{4}$ are added as limiting nutrients, and export production is now modeled through two size classes of phytoplankton, large (LP) and small (SP). We clarify that SP and LP represent downward flux of organic matter from the top two layers and not standing stocks of biomass.
The nutrient dependence of growth for the small class SP is limited by total $\mathrm{Fe}(\mathrm{FeT}), \mathrm{PO}_{4}, \mathrm{NO}_{3}$, and $\mathrm{CO}_{2}$ :

$$
\begin{array}{r}
F_{N}=\min \left\{\frac{\mathrm{FeT}}{\mathrm{FeT}+K_{\mathrm{FeT}}} \cdot \mathrm{FeT}, \frac{\mathrm{PO}_{4}}{\mathrm{PO}_{4}+K_{\mathrm{PO}_{4}}}\right. \\
\left.\cdot \mathrm{PO}_{4}, \frac{\mathrm{NO}_{3}}{\mathrm{NO}_{3}+K_{\mathrm{NO}_{3}}} \cdot \mathrm{NO}_{3}, \frac{\mathrm{CO}_{2}}{\mathrm{CO}_{2}+K_{\mathrm{CO}_{2}}} \cdot \mathrm{CO}_{2}\right\}
\end{array}
$$

where $K_{X}$ 's are half-saturation concentrations in the usual Michaelis-Menton formulation of nutrient uptake kinetics (Table 2). As noted in our description of MESMO 1, the justification for including $\mathrm{CO}_{2}$ as a possible limiting nutrient is that $\mathrm{CO}_{2}$ availability to phytoplankton may be diffusionlimited (Riebesell et al., 1993). Even though our model experiments show that $\mathrm{CO}_{2}$ does not limit production under current conditions, we keep this mechanism in place for possible use in the future under different conditions. The $K_{X}$ values used in MESMO 2/E were chosen to be consistent with MESMO 1 . For any nutrient, the MESMO1 $K_{X}$ value lies between the LP and SP $K_{X}$ values. Also, smaller values of $K_{X}$ are assigned to SP, so they have a competitive advantage in low nutrient environments over LP. This accounts for the larger surface area to volume ratio that facilitates a faster diffusive uptake of nutrients by SP.

The most limiting nutrient is identified and its uptake rate is determined by the minimum of the above equation. The uptake for other nutrients is related to the limiting nutrient by the particulate organic matter (POM) elemental stoichiometry: $\mathrm{P}: \mathrm{N}: \mathrm{C}=1: 16: 117$ and the ratios involving $\mathrm{Si}$ and $\mathrm{Fe}$ are variable as noted below. The growth of both SP and LP is also dependent on light, mixed layer depth, temperature, and biomass; these dependencies remain the same as in MESMO 1. $\mathrm{CaCO}_{3}$-forming phytoplankton such as coccolithophorids is assumed to be part of SP in MESMO 2. The dependence of $\mathrm{CaCO}_{3}$ production on carbonate ion saturation concentration remains the same as in MESMO 1.

The large phytoplankton class LP essentially represents diatoms, so its nutrient dependence term is further limited by silicic acid with an additional term for $\mathrm{Si}(\mathrm{OH})_{4}$ in Eq. (1). Since diatoms are commonly assumed to be competitive when $\mathrm{Si}(\mathrm{OH})_{4}$ is available, LP increases until $\mathrm{Si}(\mathrm{OH})_{4}$ is nearly completely drawn down. The rate of $\mathrm{Si}(\mathrm{OH})_{4}$ utilisation follows the Michaelis-Menton kinetics with a half saturation concentration shown in Table 2 . Silicic acid utilisation also depends on the bioavailability of iron such that its uptake relative to nitrate (i.e., the $\mathrm{Si}: \mathrm{N}$ uptake ratio) increases with decreasing iron (Franck et al., 2000; Hutchins and Bruland, 1998; Takeda, 1998). As a result, the stoichiometry of Si to other nutrients $\mathrm{P}$ and $\mathrm{C}$ also changes. In MESMO $2, \mathrm{Si}: \mathrm{N}$ uptake follows an inverse relation $\left(\mathrm{Si}: \mathrm{N}=0.2 \times 10^{-9} \times[\mathrm{Fe}]^{-1}\right.$, where $[\mathrm{Fe}]$ is mol-Fe $\mathrm{kg}^{-1}$ ), with minimum value capped at 0.3 following the data-based estimation (see Fig. 2c of Sarmiento et al., 2004) in the North Atlantic.

Within the present-day water column, opal particles experience dissolution, whose rate depends on the ambient 
temperature and the degree to which the local seawater is undersaturated with respect to the solid phase. The formulation for water column dissolution, including parameter values, follows Ridgwell et al. (2002). Because MESMO 2 is not coupled to a sediment model, any particle that reaches the sea floor dissolves completely and $\mathrm{Si}(\mathrm{OH})_{4}$ is returned to the overlying water.

MESMO 2 calculates the seawater $\delta^{30} \mathrm{Si}$ or the relative abundance of ${ }^{30} \mathrm{Si}$ compared to the more common and lighter isotope ${ }^{28} \mathrm{Si}$. Because marine diatoms fractionate against ${ }^{30} \mathrm{Si}$ during silicic acid fixation, $\delta^{30} \mathrm{Si}$ is believed to reflect the degree to which $\mathrm{Si}(\mathrm{OH})_{4}$ is utilised by diatoms (De La Rocha et al., 1998). The fractionation factor during $\mathrm{Si}(\mathrm{OH})_{4}$ fixation in MESMO 2 is set to 0.9989 or $-1.1 \%$ (De La Rocha et al., 1997):

${ }^{30} \alpha=\frac{R_{\mathrm{opal}}}{R_{\mathrm{Si}(\mathrm{OH})_{4}}}=0.9989$,

where $R_{\mathrm{Opal}}$ and $R_{\mathrm{Si}(\mathrm{OH})_{4}}$ are the standard ratios of the rare isotope $\left({ }^{30} \mathrm{Si}\right)$ to the most abundant isotope $\left({ }^{28} \mathrm{Si}\right)$.

The starting point of MESMO 2 iron cycle is the basic Fe code of the GENIE as used by Annan and Hargreaves (2010). The code follows the seminal modeling work of Archer and Johnson (2000), who gave a prominent role for organic ironbinding ligands in controlling the oceanic iron concentration. While the vertical profile of FeT is nutrient-like (depleted at surface), the deep ocean distribution of FeT does not exhibit the classic Atlantic-to-Pacific increase in nutrients. Although recent work indicates slightly lower FeT in the Pacific versus the Atlantic (Boyd and Ellwood, 2010), the deep ocean concentration has long been considered relatively homogeneous. As assumed by Archer and Johnson (2000), the observed FeT distribution is typically explained and modelled in terms of both iron complexation to organic ligands and removal by scavenging (Johnson et al., 1997).

In MESMO 2, iron is introduced into the ocean via atmospheric dust. For the dust deposition, the depositional flux field projected by the atmospheric tracer transport dust model of Mahowald et al. (1999) is used and re-gridded to the $36 \times 36$ equal grid of MESMO 2 .

Uniform iron content in dust of 3.5 weight $\%$ with fractional solubility of $0.2 \%$ is assumed. However, rather than apply a uniform solubility of iron in dust, solubility is instead allowed to vary inversely as a function of dust loading, consistent with laboratory experiments and observations summarised by Ridgwell (2001) as well as with a solubility that scales inversely to the square root of dust loading (Baker and Jickells, 2006). Most of the, soluble Fe is quickly bound to organic ligands according to the conditional stability or scavenging schemes of Parekh et al. (2005). FeT is the sum of free dissolved iron $\left(\mathrm{Fe}^{\prime}\right)$, which occurs in very small concentrations, and the more abundant ligand-bound iron (FeL). It is partitioned according to:

$K_{\text {ligand }}=\frac{\mathrm{FeL}}{\mathrm{Fe}^{\prime} \cdot L}$, where $L$ is the ligand concentration and set at a constant value of $1 \mathrm{nmol} \mathrm{kg}^{-1}$ everywhere. $K_{\text {ligand }}$, is the conditional stability constant (or binding strength, see Table 2). As the binding strength is increased, iron binds more strongly to ligands, increasing FeL and thus FeT in the water column. Any remaining free iron is quickly scavenged by sinking POM and is modeled, also after Parekh et al. (2005), as:

$J_{\mathrm{Fe}}=-K_{\mathrm{sc}} \cdot \mathrm{Fe}^{\prime}$

where $K_{\mathrm{sc}}$ is the scavenging strength. It is the base scavenging strength $K_{0}\left(=0.079 \mathrm{~d}^{-1}\right)$, modified by both a particlespecific fraction and an expression for the abundance of POC with an exponential dependence:

$K_{\mathrm{sc}}=\tau \cdot K_{0} \cdot \mathrm{POC}^{0.58}$.

Here, for simplicity, we allow scavenging only by POC, and set $\tau=0.7$. These parameters are taken from the empirical determination of Honeyman et al. (1988).

In MESMO 2, phytoplankton can uptake either $\mathrm{Fe}^{\prime}$ or $\mathrm{FeL}$, and the uptake occurs with a variable $\mathrm{C}: \mathrm{Fe}$ ratio, which is dependent on FeT (Sunda and Huntsman, 1995). Phytoplankton uses iron more efficiently in low iron waters, so that the uptake $\mathrm{C}$ : Fe ratio can reach as high as 200000 in the model. As POM sinks, iron is remineralised along with other nutrients and can subsequently become scavenged again by POM or become ligand-bound and exist in the water column. The scavenged iron which escapes water column remineralisation and reaches the sea floor is then assumed to be buried in the sediments and removed from the model domain. This removal over time will balance the aeolian input at the surface.

Finally, as noted previously (Matsumoto et al., 2010), there was a minor error in the code of MESMO 1 with respect to $\mathrm{CaCO}_{3}$ remineralisation. It has an exponential formulation with a $Q_{10}=2$ dependence on temperature; the dependence is similar to POC remineralisation but weaker for $\mathrm{CaCO}_{3}$. The original formulation incorrectly allowed more dissolution of $\mathrm{CaCO}_{3}$ than exists under some conditions, so the fix introduces a cap on the maximum dissolution to prevent this unrealistic situation. In MESMO 2, this fix changes the global $\mathrm{CaCO}_{3}$ production by less than $1 \%$. Another minor update in MESMO 2 calculates global ocean $\mathrm{CO}_{2}$ chemistry immediately prior to model output, so that all outputs reflect the model state at the same time.

\section{Terrestrial scheme ENTS and MESMO 2E}

MESMO 2E couples MESMO 2 to the terrestrial scheme ENTS (Williamson et al., 2006), which exists as an optional module within the GENIE framework. It is a simple prognostic model of land biosphere that calculates the exchange of energy, moisture, and carbon between land and the atmosphere. Global fluxes of carbon from photosynthesis, plant 
and soil respiration, and leaf litter drive carbon stocks of land vegetation and soil. Photosynthesis has dependence on atmospheric $\mathrm{CO}_{2}$, water stress, air temperature, and biomass or vegetation fraction. Land vegetation is expressed as fractional coverage with corresponding albedo based on vegetation, soil cover, and soil type. Prognostic variables include vegetation and soil carbon as well as land surface albedo and temperature. Also, as noted above, the seasonal NCEP reanalysis winds, which drove ENTS in Williamson et al. (2006), are replaced in MESMO 2E by the same seasonal ECMWF reanalysis winds that now drive the ocean and atmosphere. The two reanalysis products are actually quite similar, so the replacement has little impact on overall model performance, but it elevates the level of consistency in the new model boundary conditions.

The original ENTS did not have carbon isotopes, which were added in MESMO 2E. During photosynthesis, land plants preferentially fix the lighter ${ }^{12} \mathrm{C}$ over ${ }^{13} \mathrm{C}$ and ${ }^{14} \mathrm{C}$, so that the biosphere becomes isotopically light and ambient air becomes heavy. In the model, a photosynthetic fractionation factor is set to 0.9815 (i.e., $-18.5 \%$ ) for ${ }^{13} \mathrm{C}$ and twice as large for ${ }^{14} \mathrm{C}$ (O'Leary, 1988). No fractionation is assumed for other terrestrial carbon processes.

Following Williamson et al. (2006), MESMO 2E is calibrated by adjusting a set of freely adjustable rate parameters in ENTS that relate to photosynthesis $(k 18)$, vegetation respiration $(k 24)$, and soil respiration $(k 29)$. The sensitivity of the model results to each of these parameters individually was first determined, then the parameter spaces defined by them were swept in an ensemble of simulations. The choice of parameters was guided by our desire to minimise the difference from published estimates of preindustrial global vegetation, stock (Olson et al., 1983), soil carbon stock (Batjes, 1995) and global carbon fluxes from IPCC (Houghton et al., 2001) (Tables 1 and 2). Our calibration of ENTS changed the land surface properties such that the land surface albedo increased and global temperatures became lower by $\sim 1{ }^{\circ} \mathrm{C}$. In order to compensate for this cooling, planetary albedo in MESMO 2E is reduced from MESMO 2, so that the total change relative to MESMO 1 is increased to $-5.5 \%$ when combined with the change already introduced to compensate for the new ice sheet albedo values (Table 2).

\section{Equilibrium runs of MESMO 2 and $2 \mathrm{E}$}

Since MESMO is a tool developed primarily to investigate ocean biogeochemistry, the new model versions were calibrated with the goal of having reasonable ocean physics with greater attention paid to reproducing key aspects of the marine silica cycle and ocean biogeochemistry in general.

Equilibrium runs were established for both MESMO 2 and MESMO 2E by spinning up the models with present-day seasonal climatological insolation, winds, and preindustrial $\mathrm{CO}_{2}$ levels. The time step is $0.01 \mathrm{yr}$ for the physical model and $0.05 \mathrm{yr}$ for the biogeochemical model, so that the latter is called once every five time steps taken by the former. Simulations were run for $5000 \mathrm{yr}$ until deep ocean natural radiocarbon concentrations reached a steady state. The distribution of radiocarbon, in turn, is a useful metric to compare and assess model physics on long timescales. In contrast, the uptake of transient tracers gives a good indication of the ventilation characteristics of the model on decadal timescales.

The Atlantic MOC of MESMO 2 has about the same strength as MESMO 1 at $12 \mathrm{~Sv}$ (Fig. 2, Table 1). It is stronger and more realistic in MESMO 2E (17 Sv), which makes the deep Atlantic younger in terms of $\Delta{ }^{14} \mathrm{C}$, slightly closer to observational mean estimates. However, the difference in natural $\Delta^{14} \mathrm{C}$ between NADW and NPDW is not as large in the new models as in observations or MESMO 1 (Fig. 3). A probably important factor controlling the spread in values is the degree to which air-sea gas exchange occurs when Antarctic Bottom Water (AABW) is formed in the models. In reality, various water mass transformation processes occur on the Antarctic continental shelves and under ice (Foster and Carmack, 1976) with very limited air-sea gas exchange. However, such localised processes are not represented in global models, in which open ocean convection, with significantly more gas exchange, typically plays a significant role in AABW formation. As shown in Fig. 1, the new ECMWF reanalysis winds are significantly stronger in the Southern Ocean than those used in MESMO 1. Gas exchange is therefore enhanced, giving higher $\Delta^{14} \mathrm{C}$ in the Southern Ocean both at the surface and thus at depth. This likely contributes to the smaller $\Delta^{14} \mathrm{C}$ difference between NADW and NPDW in MESMO 2 and 2E (Fig. 3). Other causes of a weak interbasin gradient of $\Delta^{14} \mathrm{C}$ may include excessively strong deep horizontal mixing, which may be a result of insufficient resolution of the bottom topography. Rough bottom topography may constrict near-bottom flow. Another factor may be excessively large sea ice formation, which may force open ocean convection too far north. Still, the NADW-NPDW spread in the new models is about $100 \%$, which is comparable to the Ocean Carbon Cycle Intercomparison Project (OCMIP) models (Matsumoto et al., 2004).

In the postindustrial simulations, we continue from the equilibrium runs, but force the models with observed atmospheric $\mathrm{pCO}_{2}$ and $\mathrm{pCFC}-11$. On decadal timescales, ocean ventilation is quite reasonable, as judged by the uptake of these transient tracers (Table 1). The uptake for the year 1994 is $100 \mathrm{PgC}$ of anthropogenic carbon for MESMO 2 and $101 \mathrm{PgC}$ for MESMO 2E and $0.56 \times 10^{6}$ moles of CFC-11 for MESMO 2 and $0.59 \times 10^{6}$ moles for MESMO $2 \mathrm{E}$. These are within the observational constraints of $118 \pm 19 \mathrm{PgC}$ (Sabine et al., 2004) and $0.55 \pm 0.12 \times 10^{6}$ moles CFC11 (Willey et al., 2004) and compare well against OCMIP models (Matsumoto et al., 2004). The penetration depth of these transient tracers is usually not used as a metric of ocean carbon cycle models, in part because NADW, which serves as the main conduit of transient tracer intrusion into the deep 
a) Observed $\Delta{ }^{14} \mathrm{C}$ (permil)
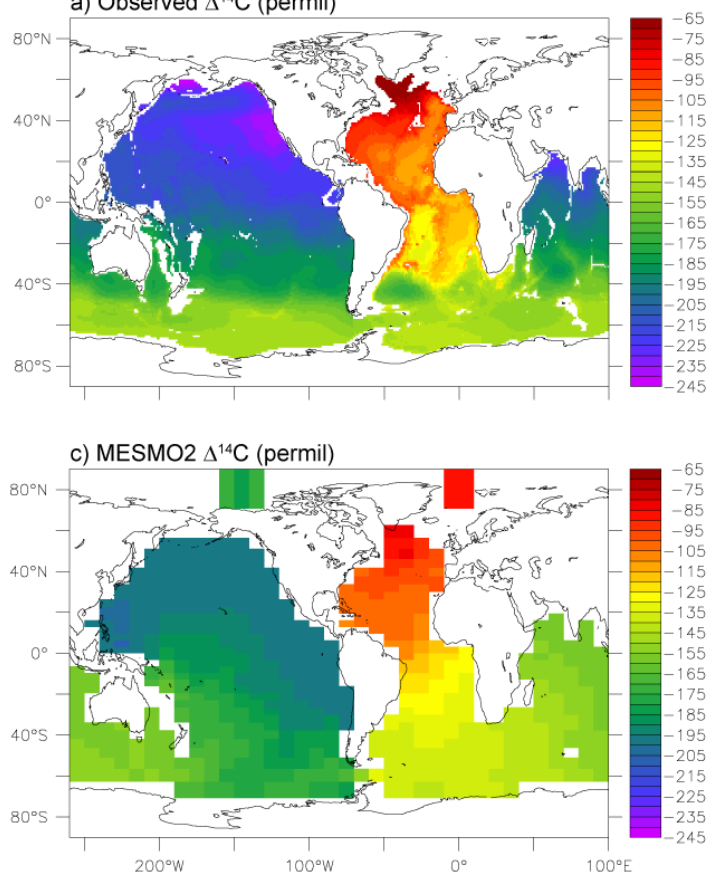
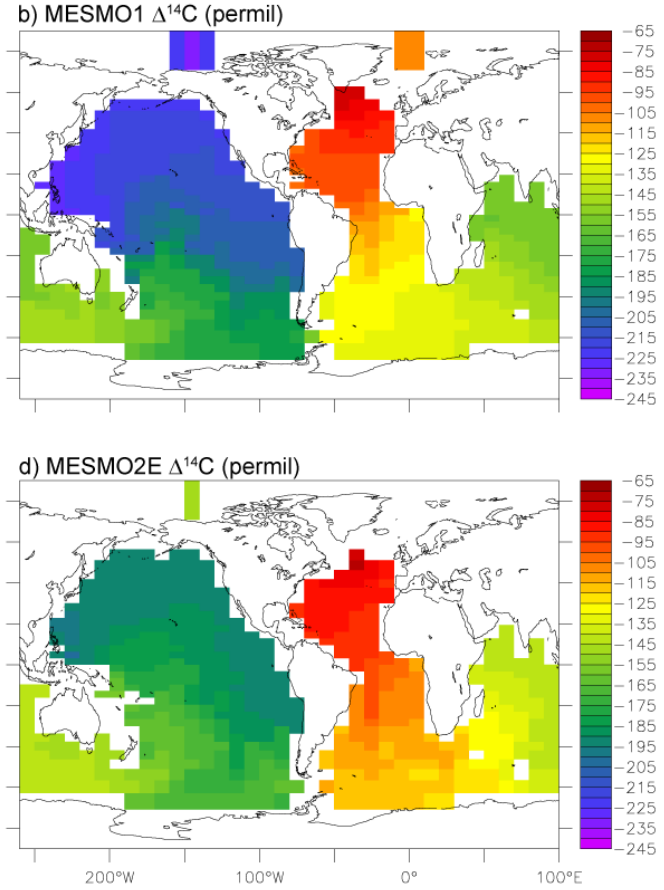

Fig. 3. Observed and model-simulated natural $\Delta^{14} \mathrm{C}$ from $2500-5000 \mathrm{~m}$ water depth. Observations are based on WOCE data (Key et al., 2004).

ocean, is consistently too shallow in OCMIP and other models (Doney et al., 2004).

In MESMO 1, the global mean surface air temperature is $11.4^{\circ} \mathrm{C}$ during the preindustrial equilibrium state (Table 1) and $12.0^{\circ} \mathrm{C}$ during the $1961-1990$ period in a postindustrial transient simulation with anthropogenic $\mathrm{CO}_{2}$ forcing. These are much colder than the data-derived, estimated temperature of $14.0^{\circ} \mathrm{C}$ for the same $1961-1990$ period (Jones et al., 1999). The model-observation discrepancy is significantly improved in the new MESMO versions. For the 1961-1990 period, the global mean surface air temperature is $14.2{ }^{\circ} \mathrm{C}$ for MESMO 2 and $14.3^{\circ} \mathrm{C}$ for MESMO 2E for postindustrial transient simulations. These are $0.7^{\circ} \mathrm{C}$ warmer than their respective preindustrial equilibrium temperatures (Table 1). As would be expected, the coarse resolution of MESMO makes it difficult to sustain strong gradients of, for example, surface air temperature (Fig. 4) or sea surface temperature (Fig. 5). Consequently, air temperature tends to be longitudinally smooth, and the western warm pool is not as warm in the models as observed.

In terms of seasonal sea ice extent, the new models show improvement over MESMO 1, but still overestimate it when compared to observations (Table 1, Fig. 6). It is important to keep in mind that as with global mean surface air temperature, sea ice extent presented in Table 1 represents the preindustrial equilibrium state for the models, not some postindustrial period for the observational constraints. The Arctic sea ice extent in February is $20.3 \times 10^{6} \mathrm{~km}^{2}$ in MESMO 2 and $18.5 \times 10^{6} \mathrm{~km}^{2}$ in MESMO 2E, compared to satellite derived estimate of $14-16 \times 10^{6} \mathrm{~km}^{2}$ (Table 1). The overestimation is smaller, because global sea ice extent is $8-10 \%$ smaller in year 2000 than during the preindustrial state in the two models. Nevertheless sea ice extends much further south in the far North Atlantic in all versions of MESMO compared to observations (Fig. 6). This reflects the fact that open ocean convection that occurs in reality in the Greenland-Ice Land-Norwegian Seas and leads to the formation of NADW occurs too far south in the models. In the Antarctic, the September sea ice extent is $33.0 \times 10^{6} \mathrm{~km}^{2}$ in MESMO 2 and $25.5 \times 10^{6} \mathrm{~km}^{2}$ in MESMO 2E, compared to satellite derived estimate of $17-20 \times 10^{6} \mathrm{~km}^{2}$ (Table 1). Again, the discrepancy would be smaller is smaller for the same reference time.

\subsection{Ocean biogeochemistry}

The values for the new biogeochemical parameters (Table 2) were tuned on the basis of experimental experience with the goal of achieving reasonable global production rates, and spatial distributions of POC, $\mathrm{CaCO}_{3}$, and opal (Table 1). We note that the starting point of this tuning was MESMO 1, which was objectively tuned (Matsumoto et al., 2008), and that subjective tuning has yielded superior results to objective tuning in an earlier tuning exercise of GENIE (Lenton et al., 2006) and remains a primary method of tuning (Marsh et al., 2011). In our tuning, we also targeted selected features of the iron and silica cycles. One of the iron targets is the deep water FeT concentrations of $0.6-0.7 \mathrm{nmol} \mathrm{kg}^{-1}$. Another is 

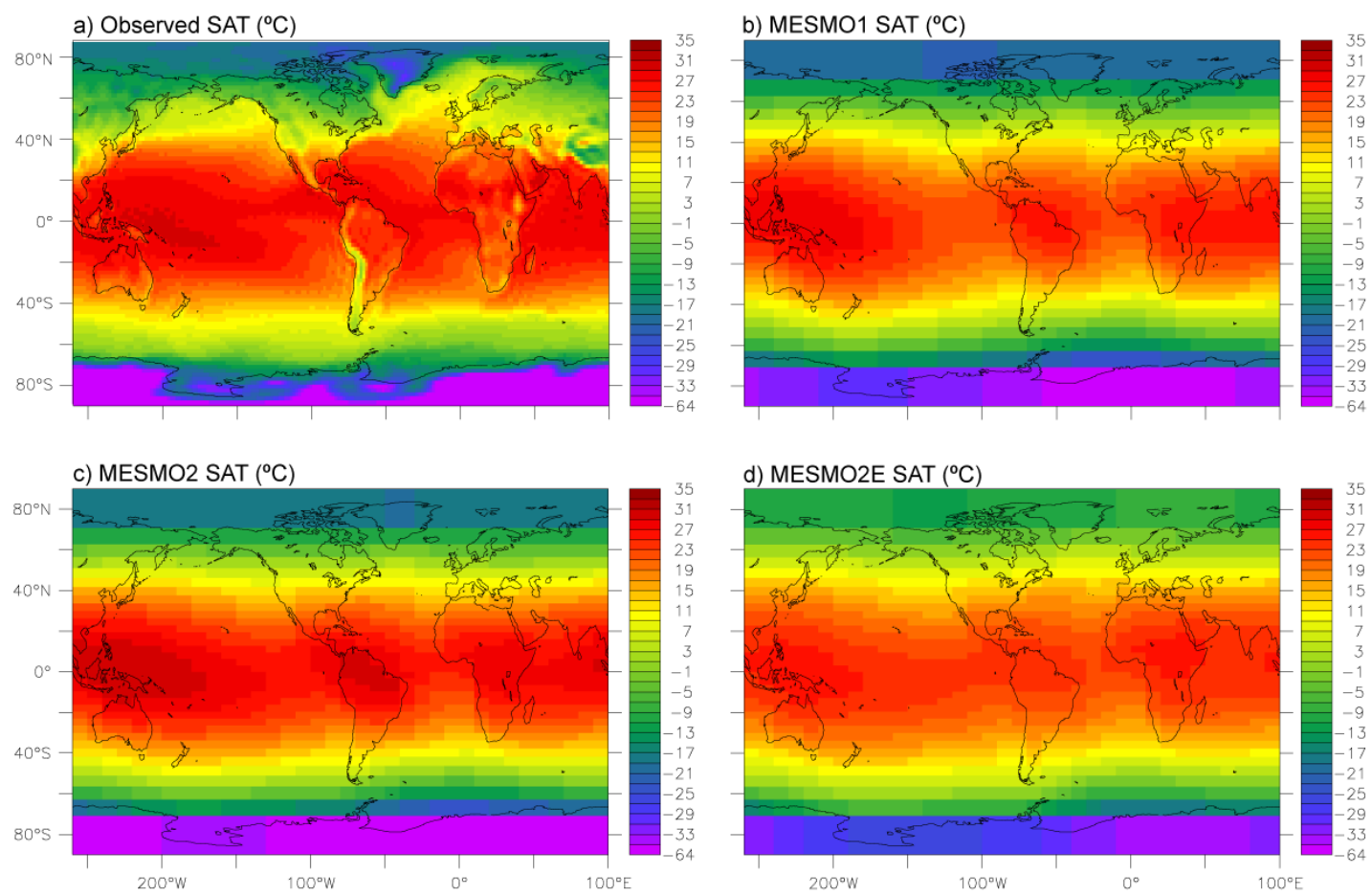

Fig. 4. Observed and model-simulated annual mean surface air temperature. Observations are based on the NCEP/NCAR $40 \mathrm{yr}$ reanalysis (Kalnay et al., 1996).

a) Observed SST $\left({ }^{\circ} \mathrm{C}\right)$

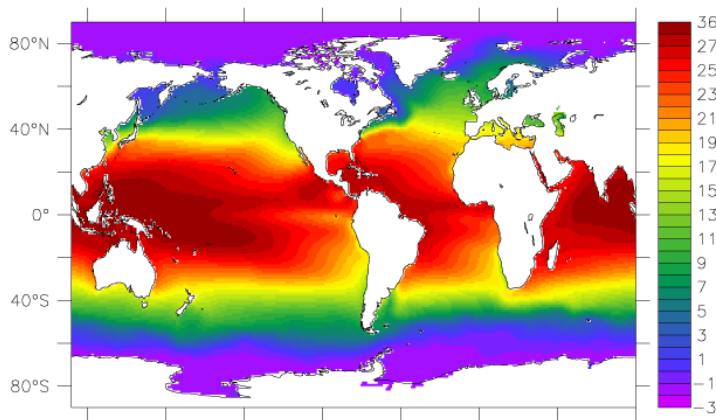

c) MESMO2 SST $\left({ }^{\circ} \mathrm{C}\right)$

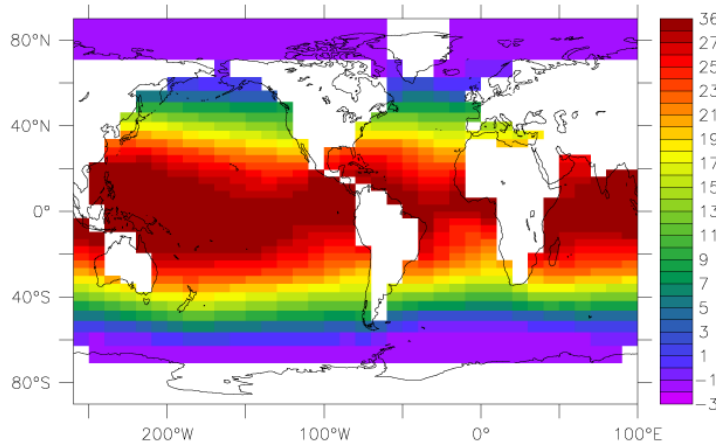

b) MESMO1 SST $\left({ }^{\circ} \mathrm{C}\right)$

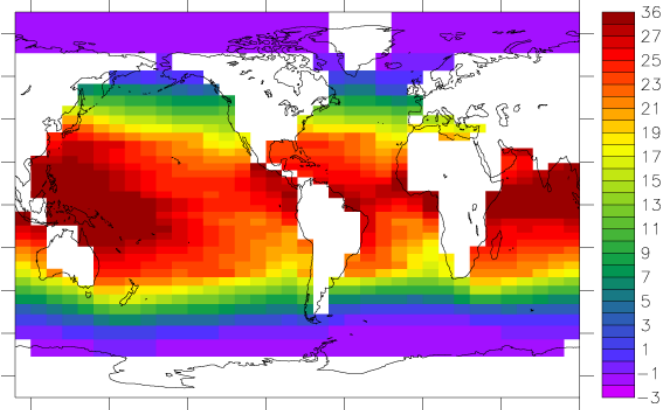

d) MESMO2E SST ( $\left.{ }^{\circ} \mathrm{C}\right)$

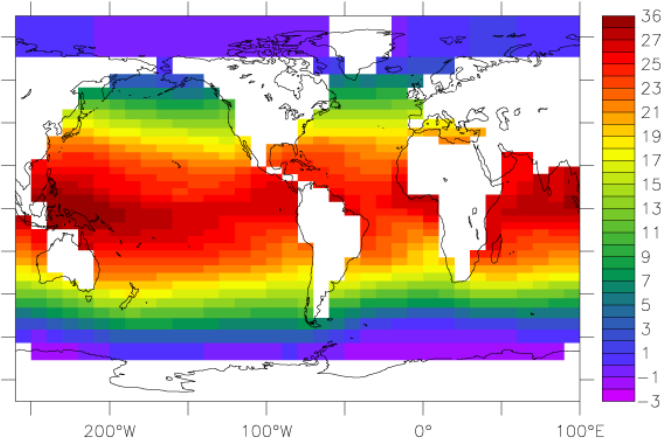

Fig. 5. Observed and model-simulated mean annual sea surface temperature (top $45 \mathrm{~m}$ ). Observations are based on the World Ocean Atlas 2009 (Locarnini, 2010). 


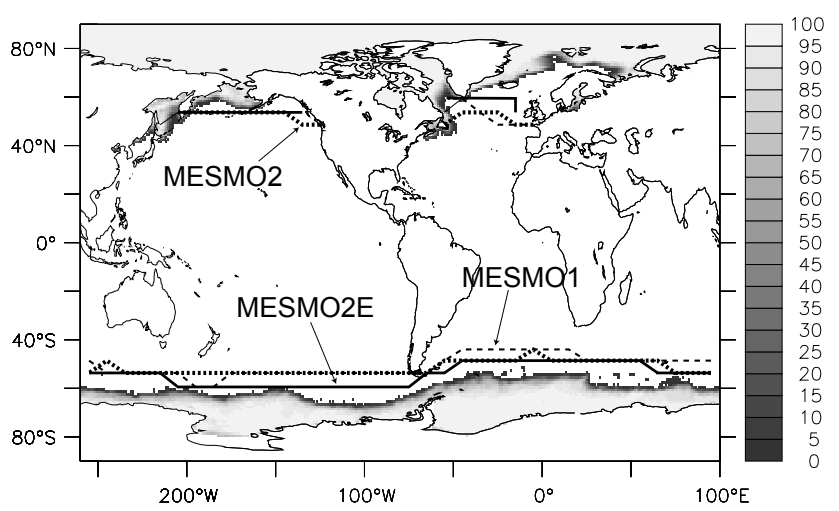

Fig. 6. Observed and model-simulated maximum seasonal sea ice extent. Observations indicated in greyscale are based on satellitebased passive microwave data (1/1987-12/1988) archived at the National Snow and Ice Data Center (A. Nomura and R. Grumbine, personal communication, 1995).

surface FeT concentrations that are low enough for the $\mathrm{Si}$ : N uptake ratio to be elevated in the Southern Ocean and the far North Pacific as observed (Sarmiento et al., 2004). Finally, iron has to be limiting production in the Southern Ocean. The two important targets with respect to the marine silica cycle are the export of $\mathrm{Si}(\mathrm{OH})_{4}$-depleted waters from the Southern Ocean to the rest of the world ocean via Antarctic Intermediate and/or Mode Waters and the consequent $\mathrm{Si}(\mathrm{OH})_{4}$ limitation for LP outside the Southern Ocean. Regarding the latter silica target, we note that while observations suggest that diatoms in much of the lower latitudes is limited by silicic acid limitation (Sarmiento et al., 2004), the ecosystem modelling work of Moore et al. (2002) indicates that silicic acid limitation is actually quite small and that iron limitation is much more significant.

The global export production of POC is $11.9 \mathrm{PgC} \mathrm{yr}^{-1}$ in MESMO 2 and 12.5 $\mathrm{PgC} \mathrm{yr}^{-1}$ in MESMO 2E (Table 1). These are consistent with a recent synthesis of particle export production, in which Dunne et al. (2007) give their best estimate as 9.6 $\pm 3.6 \mathrm{PgC} \mathrm{yr}^{-1}$ for POC. Previous estimates ranged between 5.8 and $12.9 \mathrm{PgC} \mathrm{yr}^{-1}$. Of the simulated global production, the majority is due to LP: 8.7 out of $11.9 \mathrm{PgC} \mathrm{yr}^{-1}$ in MESMO 2 and 9.2 out of $12.5 \mathrm{PgC} \mathrm{yr}^{-1}$ in MESMO 2E. Unfortunately, the proportion of total export production which can be attributed to diatoms is not well understood from observations, with estimates ranging between 20 and $90 \%$ (Sarmiento and Gruber, 2006). As expected, total production is lowest in the nutrient poor oligotrophic gyres (Fig. 7a). The contribution of SP to the total production is highest in oligotrophic gyres, given the lower half saturation values in SP that give it competitive advantage over LP (Fig. 7b).

The simulated global $\mathrm{CaCO}_{3}$ production is $1.0 \mathrm{PgC} \mathrm{yr}^{-1}$ by MESMO 2 and $0.9 \mathrm{PgC} \mathrm{yr}^{-1}$ by MESMO 2E (Table 1). These are comparable to MESMO 1 but higher than the best estimate of Dunne et al. (2007) of $0.52 \pm 0.15 \mathrm{PgC} \mathrm{yr}^{-1}$. They note, though, that constraining the global $\mathrm{CaCO}_{3}$ export has been controversial and that previous estimates ranged from 0.38 to $4.7 \mathrm{PgC} \mathrm{yr}^{-1}$ with most estimates occupying the lower end of the range.

The global export production of opal is also not well constrained by data. According to Dunne et al. (2007), historical estimates have ranged from 70 to $185 \mathrm{Tmol} \mathrm{Si} \mathrm{yr}^{-1}$ $\left(\mathrm{Tmol}=10^{12} \mathrm{~mol}\right)$, while their best estimate is $101 \pm$ $35 \mathrm{Tmol} \mathrm{Si} \mathrm{yr}^{-1}$. Global export is $130 \mathrm{Tmol} \mathrm{Si} \mathrm{yr}^{-1}$ in MESMO 2 and $139 \mathrm{Tmol} \mathrm{Si} \mathrm{yr}^{-1}$ in MESMO 2E (Table 1). The majority of the export production occurs in the Southern Ocean and a secondary peak in the North Pacific (Fig. 7c); this spatial pattern is consistent with Dunne et al. (2007).

In both MESMO 2 and 2E, FeT is higher in the Atlantic than in the Pacific. At the surface, FeT is high in the North Atlantic, which reflects the large aeolian input of Fe from the African Sahara, and also around Antarctica, where there is deep upwelling (Fig. 7d). Since the $\mathrm{Si}$ : N uptake ratio by diatoms is inversely related to $\mathrm{Fe}$ availability, the $\mathrm{Si}: \mathrm{N}$ uptake ratio by diatoms is very low in the North Atlantic (Fig. 7e). Conversely $\mathrm{Fe}$ limitation in the Southern Ocean and the North Pacific, two well know HNLC regions, cause the $\mathrm{Si}: \mathrm{N}$ uptake ratio in those regions to be high. These spatial features are consistent with data-based uptake ratio (Sarmiento et al., 2004). At depth, the simulated FeT is approximately $0.65 \mathrm{nmol} \mathrm{kg}^{-1}$ in the Atlantic and about $0.6 \mathrm{nmol} \mathrm{kg}^{-1}$ in the Pacific (Fig. 7f). Available data also show lower FeT in the deep Pacific, which has the oldest waters and thus has experienced the most scavenging (Boyd and Ellwood, 2010).

The subtropical gyres evident in terms of various diagnostics of model production (Fig. 7) clearly have depleted $\mathrm{PO}_{4}$ concentrations in the top $100 \mathrm{~m}$, although the depletion is stronger in observation (Fig. 8). Also, compared to MESMO 1, both MESMO 2 and 2E have a more pronounced and improved expression of eastern equatorial upwelling in terms of $\mathrm{PO}_{4}$, driven by seasonally stronger new wind fields.

In the two new models, $\mathrm{Fe}$ is the limiting nutrient in the Southern Ocean for both SP and LP (Fig. 9). For SP, Fe is also limiting in the Arctic, but otherwise, nitrate is the limiting nutrient in much of the world ocean. Diatoms (LP), are mostly limited by $\mathrm{Si}(\mathrm{OH})_{4}$ outside the Southern Ocean, which is consistent with observations (Sarmiento et al., 2004). There is no $\mathrm{Si}(\mathrm{OH})_{4}$ limitation in the North Atlantic, where the high aeolian dust flux and thus high surface $\mathrm{FeT}$ reduce both the $\mathrm{Si}: \mathrm{N}$ uptake ratio (Fig. 7e) and the demand for $\mathrm{Si}(\mathrm{OH})_{4}$.

Partly as a result of this reduced demand, $\mathrm{Si}(\mathrm{OH})_{4}$ in the surface subpolar North Atlantic is fairly high in the model in contrast to observations (Fig. 10a and b). In observations, $\mathrm{Si}(\mathrm{OH})_{4}$ is rather depleted there despite the low $\mathrm{Si}: \mathrm{N}$ uptake (Sarmiento et al., 2004), because large Saharan iron input and seasonal blooms drive strong opal export. In the models however, diatoms in the North Atlantic do not respond readily to the Sahara iron, since they are more $\mathrm{NO}_{3}$ limited (Fig. 9) 

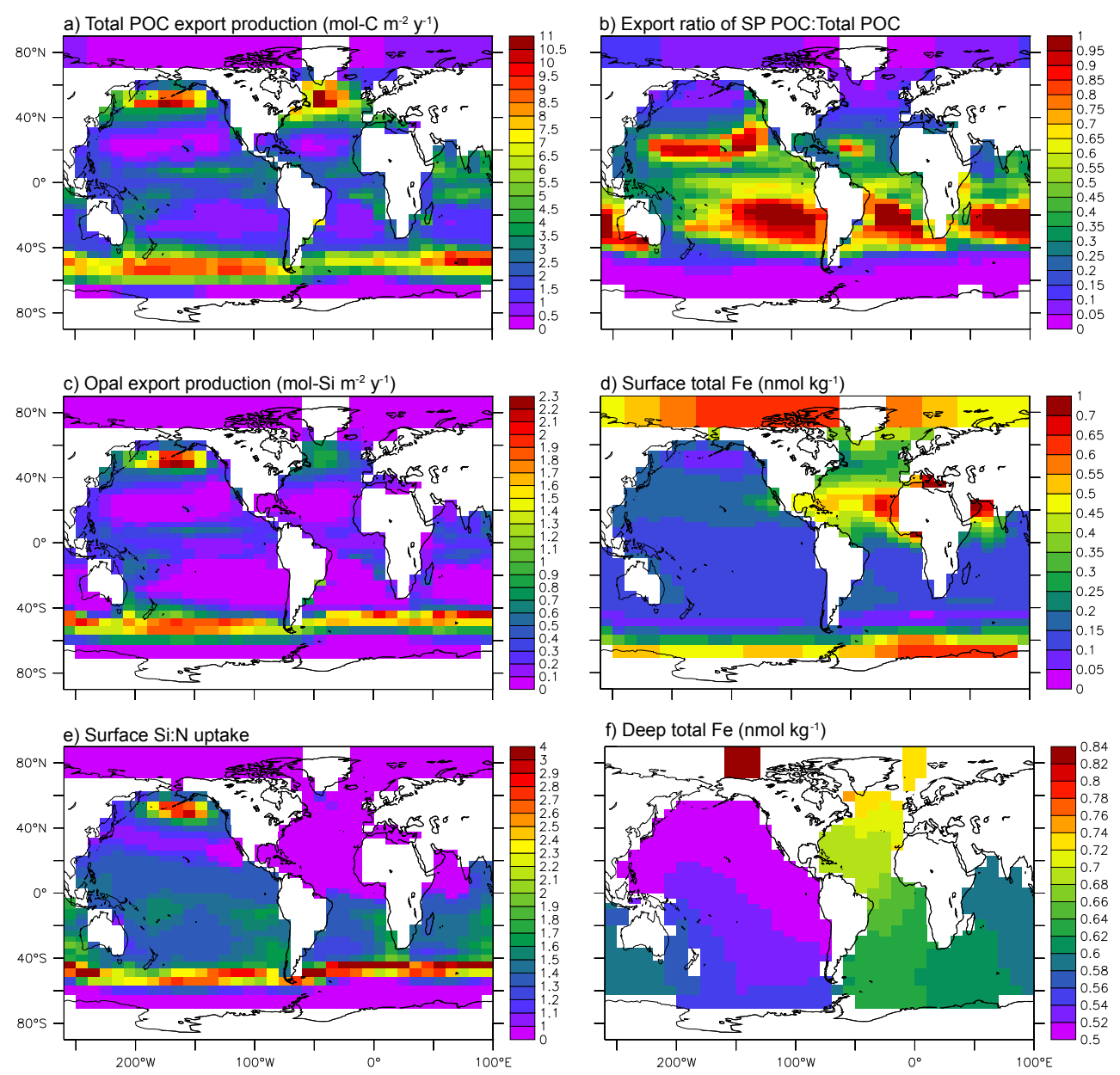

Fig. 7. Simulated annual mean results from MESMO 2: (a) POC export production; (b) fractional contribution of the small phytoplankton to the total POC export production; (c) opal export production; (d) surface FeT concentration; (e) $\mathrm{Si}: \mathrm{N}$ uptake ratio by diatoms; (f) mean FeT in $2000-4000 \mathrm{~m}$.

and seasonal variability is typically too small. This modeldata disagreement therefore indicates a limitation of our relatively simple ecosystem model. Elsewhere though, the new models capture observations reasonably well. For example, the surface North Pacific does not experience $\mathrm{Si}(\mathrm{OH})_{4}$ limitation and has elevated concentrations of $\mathrm{Si}(\mathrm{OH})_{4}$ in both the models and data (Fig. 10a and b). In the Southern Ocean, the high $\mathrm{Si}: \mathrm{N}$ uptake rate of $\mathrm{Si}(\mathrm{OH})_{4}$ in the Southern Ocean causes its depletion there. The degree to which $\mathrm{Si}(\mathrm{OH})_{4}$ is depleted is commonly expressed in relation to nitrate as $\mathrm{Si}^{*}$ $\left(\mathrm{Si}^{*}=\left[\mathrm{Si}(\mathrm{OH})_{4}\right]-\left[\mathrm{NO}_{3}\right]\right)$. Negative values of $\mathrm{Si}^{*}$ indicate $\mathrm{Si}(\mathrm{OH})_{4}$-depleted waters at the surface (Fig. $10 \mathrm{c}$ and d). As seen in available data (Brzezinski et al., 2002; Sarmiento et al., 2004), the new model has this depletion signal spreading out from the Southern Ocean to the rest of the ocean via Antarctic Intermediate/Mode Water (Fig. 10e and f). There may also be a surface contribution to this spreading. We believe that some form of southern sourced intermediate water does exist in MESMO 2 despite its coarse model resolution, because there is a tongue of low salinity water originating from the surface Southern Ocean and penetrating northward (Fig. 10g and h). This tongue is prominent in the Atlantic sector, but less so in the Pacific sector.

We note that these $\mathrm{Si}^{*}$ features provided the original motivation to develop MESMO 2. There is a hypothesis that the $\mathrm{Si}(\mathrm{OH})_{4}$ depletion observed in the modern Southern Ocean can be reversed during times of high dust or iron input such as the glacial periods. The consequent reorganisation of the global silica cycle could help explain some of the variability in atmospheric $\mathrm{CO}_{2}$ levels (Brzezinski et al., 2002; Matsumoto et al., 2002). There have been a number of paleoceanographic studies that directly attempted to test this hypothesis with as yet no conclusive verdict (Matsumoto and Sarmiento, 2008). The ability of MESMO 2 to reasonably reproduce key $\mathrm{Si}^{*}$ features makes the model potentially useful in investigating the biogeochemical implications of climatecarbon feedbacks involving diatoms. 

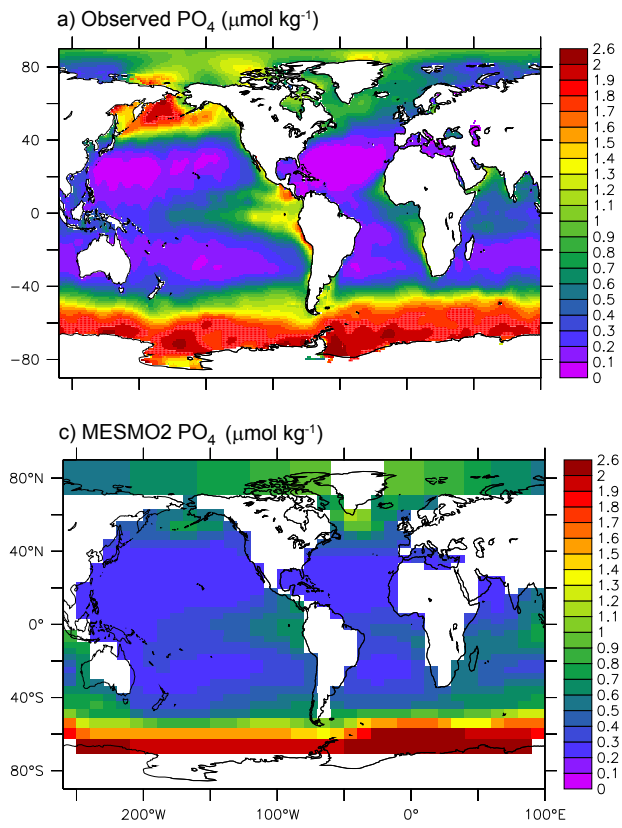

b) MESMO1 $\mathrm{PO}_{4}\left(\mu \mathrm{mol} \mathrm{kg}{ }^{-1}\right)$

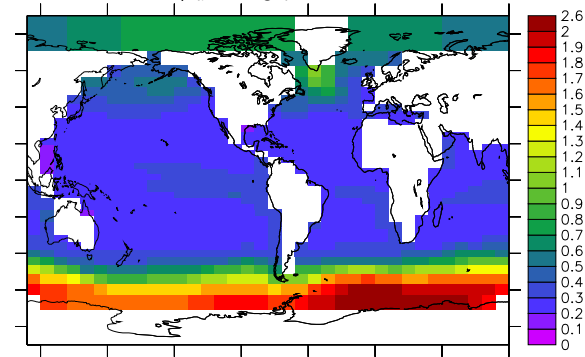

d) MESMO2E $\mathrm{PO}_{4}\left(\mu \mathrm{mol} \mathrm{kg}{ }^{-1}\right)$

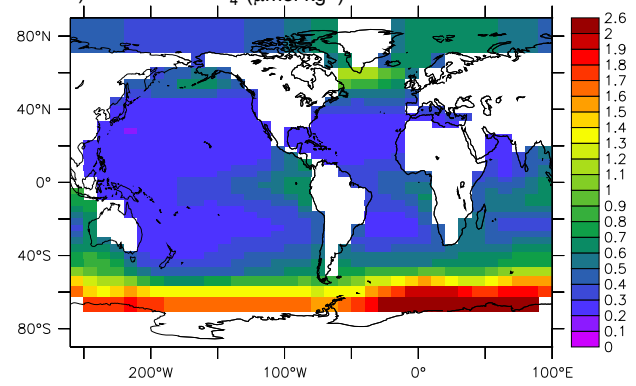

Fig. 8. Observed and model-simulated annual mean $\mathrm{PO}_{4}$ concentration in the top $45 \mathrm{~m}$. Observations are based on the World Ocean Atlas 2009 (Garcia, 2010).

a) SP Nutrient limitation

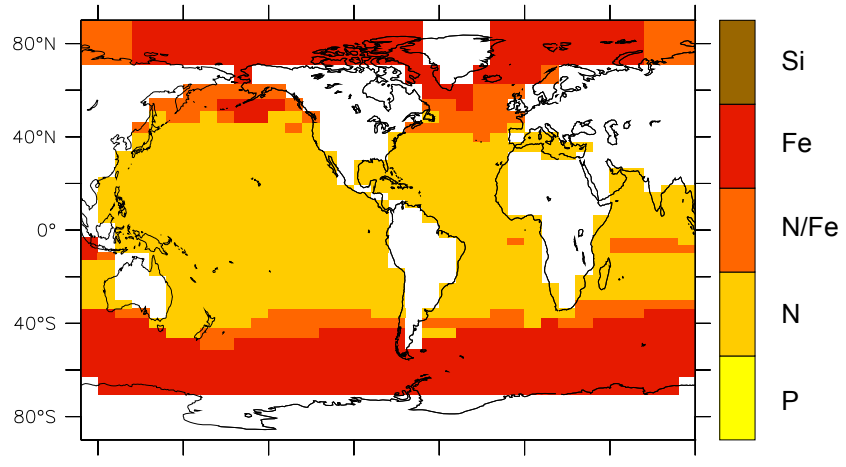

b) LP Nutrient limitation

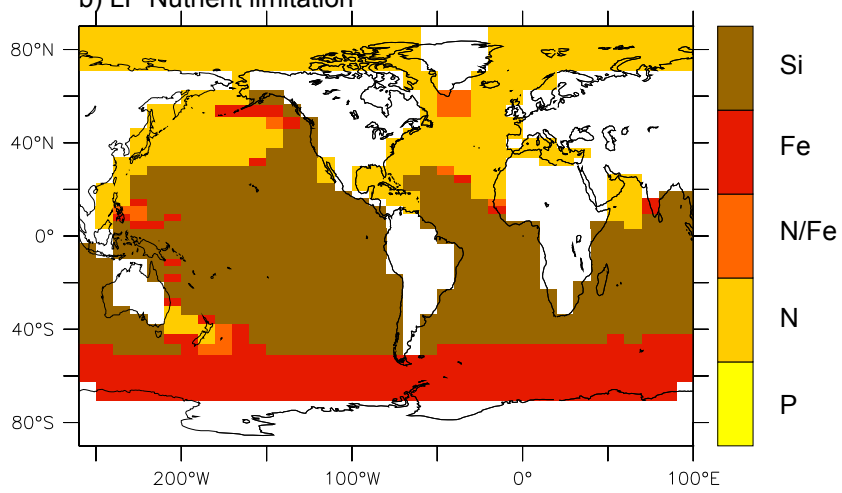

Fig. 9. Simulated annual mean nutrient limitations for the small phytoplankton (a) and large phytoplankton (b) from MESMO 2.
Another useful tracer in this regard is seawater $\delta^{30} \mathrm{Si}$, which becomes heavier in a parcel of seawater as $\mathrm{Si}(\mathrm{OH})_{4}$ utilisation increases. Measurements of $\delta^{30} \mathrm{Si}$ in deep sea sediments offer an exciting possibility to investigate past changes in the marine silica cycle. Already a number of studies have made measurements of different sedimentary fractions such as opal (Horn et al., 2011) and sponge spicules (Ellwood et al., 2010).

To date, there are two modelling studies of seawater $\delta^{30} \mathrm{Si}$. First, Wischmeyer et al. (2003) used an ocean general circulation model with a prognostic $\mathrm{PO}_{4}$-based export production, which is then related to $\mathrm{Si}$ production. Second, Reynolds (2009) used a box model, in which diagnostic $\mathrm{PO}_{4-}$ based production is again related to $\mathrm{Si}$ production. With a more realistic and mechanistic representation of the marine silica cycle, MESMO 2 makes significant improvements over these earlier efforts. As in Wischmeyer et al. (2003), the $-1.1 \%$ ofractionation during silicic acid uptake in our model imparts a heavy $\delta^{30} \mathrm{Si}$ signal to very near surface waters (Fig. 11a) that correspond to a higher degree of $\mathrm{Si}(\mathrm{OH})_{4}$ utilisation (Fig. 11b). Our simulated vertical profile of $\delta^{30} \mathrm{Si}$ is consistent with recent water column data from the Atlantic, which show $\delta^{30} \mathrm{Si}$ "from approximately $+1.2 \%$ in bottom waters to almost $+3 \%$ o in the surface mixed layer" with strong enrichment occurring near the surface (Souza et al., 2012). The surface distribution of simulated $\delta^{30} \mathrm{Si}$ (Fig. 11c) resembles the simulated patterns of $\mathrm{PO}_{4}$ and $\mathrm{POC}$ production (Figs. 7 and 8) in that the subtropical gyres generally have low nutrients and, therefore, lower overall production but higher fraction of SP and higher degree of nutrient utilisation. 

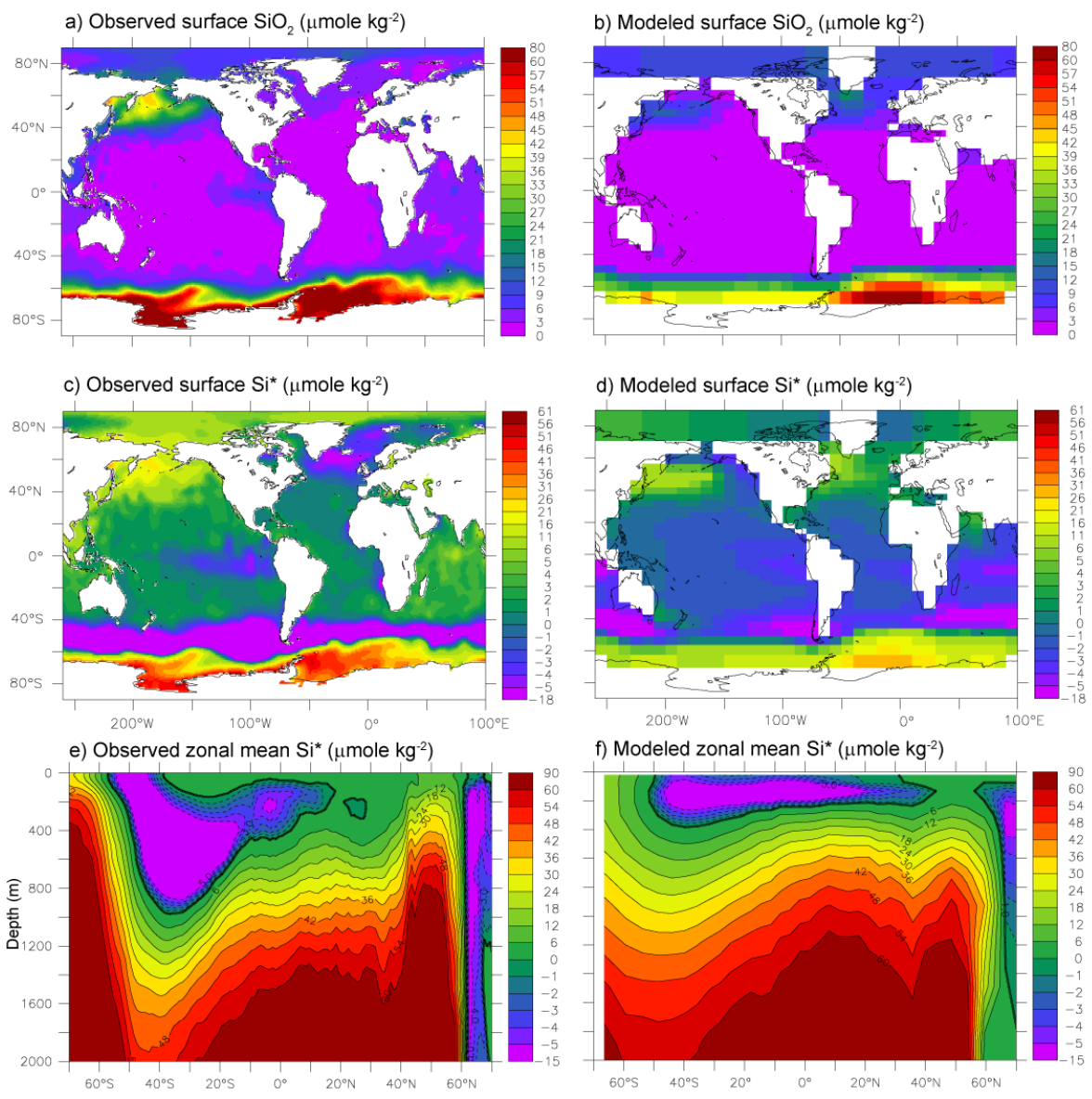

f) Modeled zonal mean $\mathrm{Si}^{*}\left(\mu\right.$ mole $\left.\mathrm{kg}^{-2}\right)$
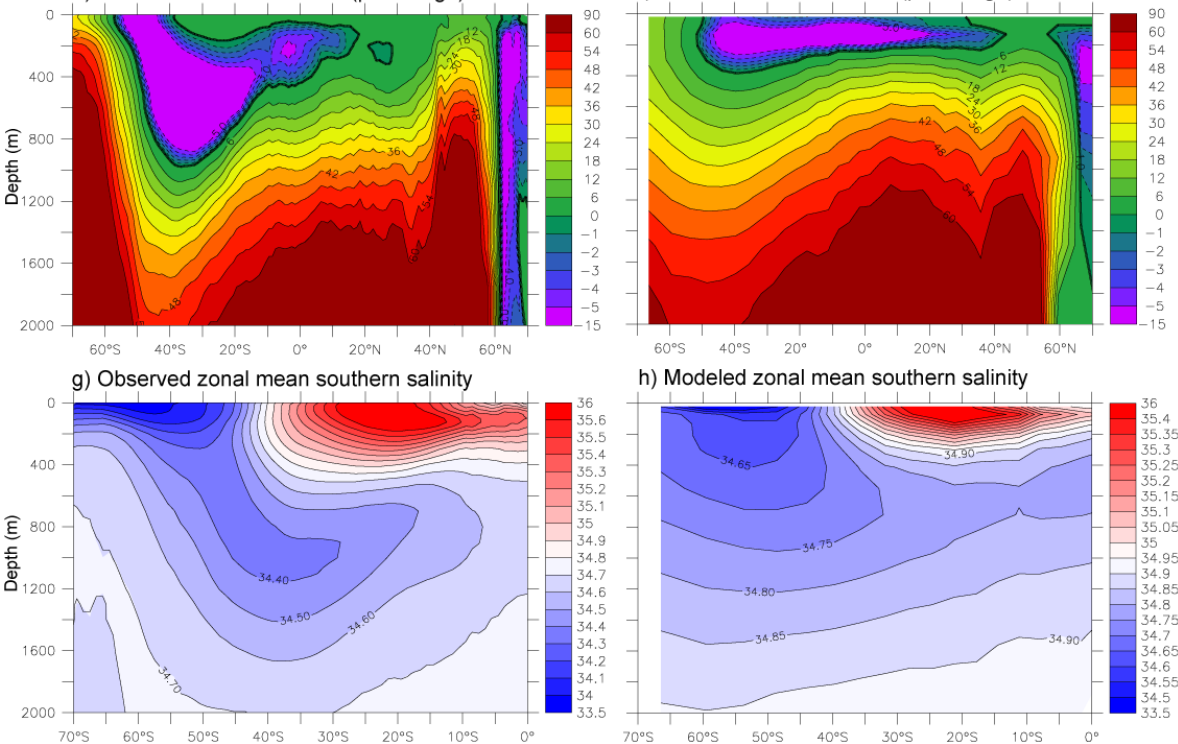

h) Modeled zonal mean southern salinity

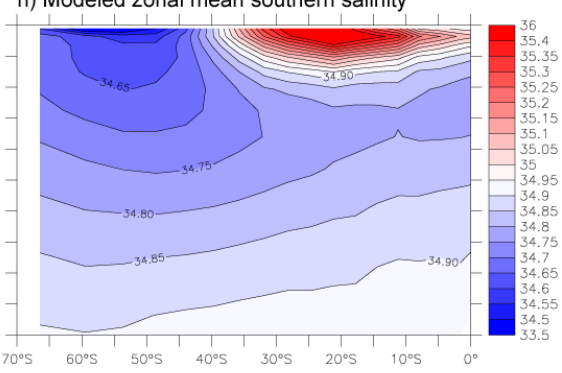

Fig. 10. Observed and model-simulated annual mean silica cycle diagnostics and salinity: (a, b) surface $\mathrm{Si}(\mathrm{OH})_{4}$; $(\mathbf{c}, \mathbf{d})$ surface $\mathrm{Si}$ * concentration; (e, f) global zonally averaged $\mathrm{Si}^{*}$ concentration; $(\mathbf{g}, \mathbf{h})$ zonally averaged, Southern Hemisphere salinity. Left column shows observations based on the World Ocean Atlas 2009 (Antonov, 2010; Garcia, 2010). The right column shows model results from MESMO 2. Surface indicates top $45 \mathrm{~m}$. Negative $\mathrm{Si}^{*}$ indicates Si deficiency; see text.

However, the $\delta^{30} \mathrm{Si}$ map is more complicated, because surface $\mathrm{Si}(\mathrm{OH})_{4}$ is decoupled from other nutrients though its dependence on $\mathrm{Fe}$ and variable $\mathrm{Si}: \mathrm{N}$ uptake ratio. In the model, there is a deep $\delta^{30} \mathrm{Si}$ gradient that shows enrichment in the Arctic and the North Atlantic compared to relatively low values in the Southern Ocean (Fig. 11d). A qualitatively similar gradient is also observed in the Atlantic albeit larger (Souza et al., 2012).

\subsection{The terrestrial biosphere}

The calibration of the ENTS parameters in MESMO 2E produces $123 \mathrm{PgC} \mathrm{yr}^{-1}$ for global net photosynthesis, $62 \mathrm{PgC} \mathrm{yr}^{-1}$ for vegetation respiration, and $61 \mathrm{PgC} \mathrm{yr}^{-1}$ for leaf litter and soil respiration (Table 1). The leaf litter flux represents the influx for soil carbon reservoir and soil respiration represents its outflux, so they are equal at steady state. These fluxes compare well to those presented by IPCC preindustrial estimates of $120 \mathrm{PgC} \mathrm{yr}^{-1}$ for photosynthesis 

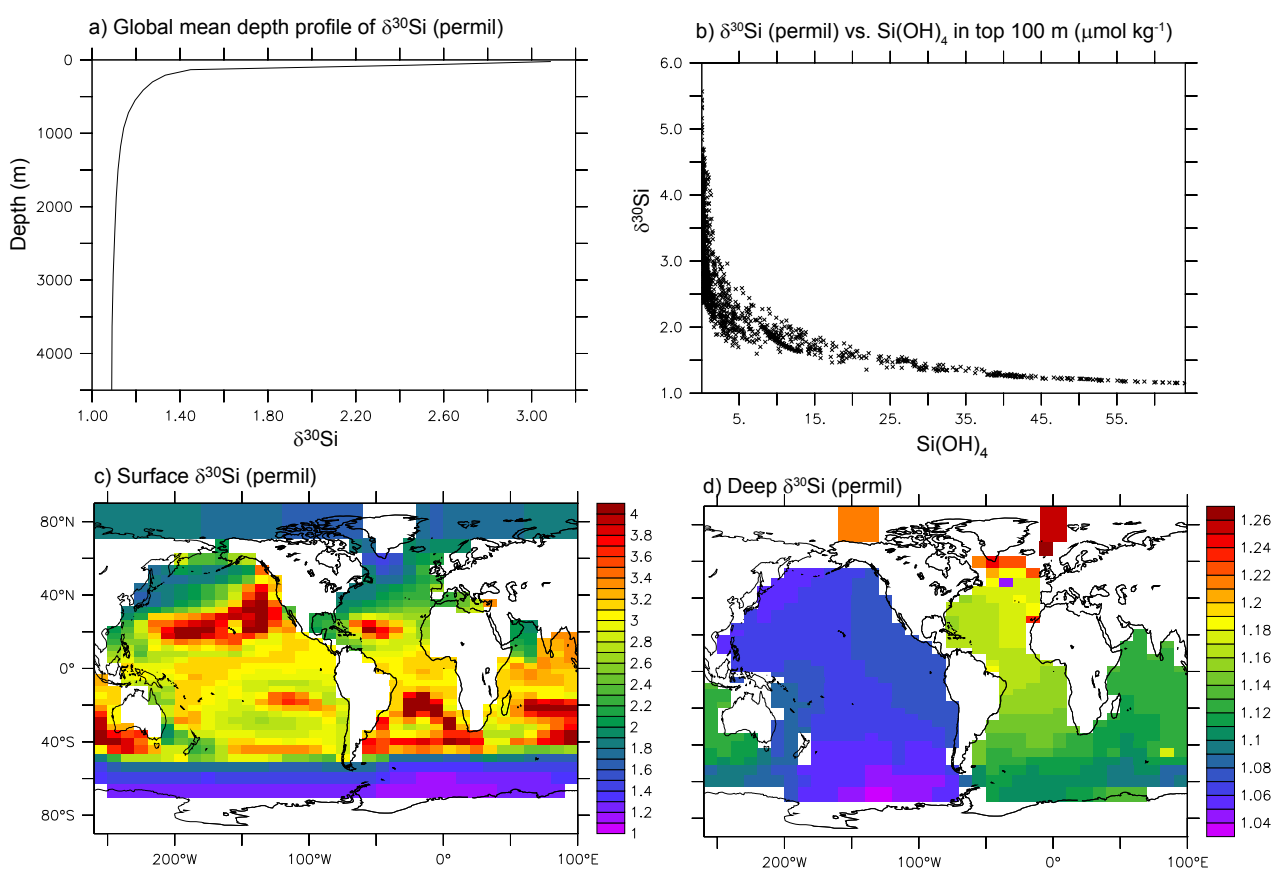

Fig. 11. Simulated annual mean $\delta^{30} \mathrm{Si}$ from MESMO 2: (a) global mean vertical profile; (b) relationship to $\mathrm{Si}(\mathrm{OH})_{4}$; (c) surface distribution; and (d) deep distribution (2000-4000 m).

and $60 \mathrm{PgC} \mathrm{yr}^{-1}$ for the other fluxes (Houghton et al., 2001). The equilibrium carbon stock in MESMO 2E is $461 \mathrm{PgC}$ in above ground vegetation and $1319 \mathrm{PgC}$ in soils (Table 1 ). In comparison, Williamson et al. (2006) simulated stocks of 437 and $1317 \mathrm{PgC}$ for vegetation and soil respectively in the original description of ENTS. The data-based targets for these stocks are $451 \mathrm{PgC}$ (Olson et al., 1985) and $1306 \mathrm{PgC}$ (Batjes, 1995), which include postindustrial land use changes and therefore are likely lower than the corresponding preindustrial stocks.

The spatial distribution in carbon vegetation compares reasonably well to observations (Hall et al., 2005): peak carbon storage in tropical rainforests and secondary maximum in boreal forests (Fig. 12a). However, the relatively simple land scheme of ENTS and the fact that precipitation in EMBM is typically underestimated and causes the continental interiors to become too dry (Marsh et al., 2011) may lead to mismatches with observation. For example, the simulated carbon stock in the boreal forest of Northern Asia may be too low. At the same time, the model captures the main desert regions of the world. Soil carbon distribution reasonably shows high values in northern boreal regions, where low temperatures limit soil respiration, and low values in the tropical regions, where temperatures and thus soil respiration rates are high (Fig. 12b). In terms of $\Delta^{14} \mathrm{C}$, the vegetation is very close to being in equilibrium with the atmosphere (i.e., $\sim 0 \%$ ), as expected. Soil is more depleted especially in cold regions such as Alaska and Siberia where low respiration rates lead to longer residence times of carbon (Fig. 12c).

\section{Summary}

Two new versions of MESMO are presented here: MESMO 2 and MESMO 2E. The only differences between the two are the coupling of a terrestrial biosphere model ENTS in the latter and the planetary albedo adjustment needed to compensate for the change in land surface albedo caused by the coupling. The physical and biogeochemical modifications described here (Table 2) correct unrealistically low surface albedo values on ice sheets, introduce more seasonality, and allow more explicit representation of the marine silica cycle as compared to MESMO 1.

The use of the same seasonal ECMWF winds to drive all aspects of MESMO 2 removes the inconsistency that existed in the previous version, in which different wind products were used to drive ocean dynamics, air-sea gas exchange, atmospheric heat and moisture transport, and ENTS. Compared to the earlier annual winds, the new seasonal winds impart more momentum to the ocean, especially the Southern Ocean, causing the ocean interior to become excessively well ventilated. This necessitated adjustments in the existing wind scaling factor and interbasin freshwater flux in order to realise distributions of natural ${ }^{14} \mathrm{C}$ and anthropogenic transient tracers that are consistent with observations.

The implementations of the iron cycle, two classes of phytoplankton, and a dependence of the $\mathrm{Si}(\mathrm{OH})_{4}$ utilisation on Fe availability are sufficient to simulate key features of the marine silica cycle in MESMO 2. They include $\mathrm{Si}(\mathrm{OH})_{4}$ limitation for diatoms in much of the low latitude oceans, 
a) Vegetation carbon $\left(\mathrm{kg} \mathrm{m}^{-2}\right)$

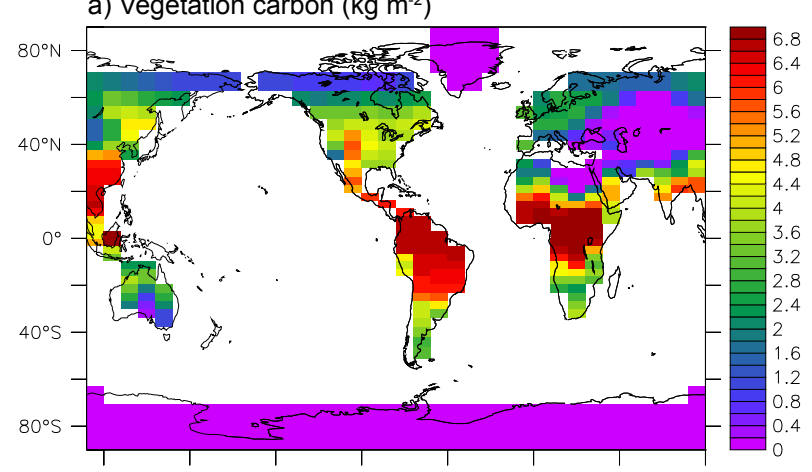

b) Soil carbon

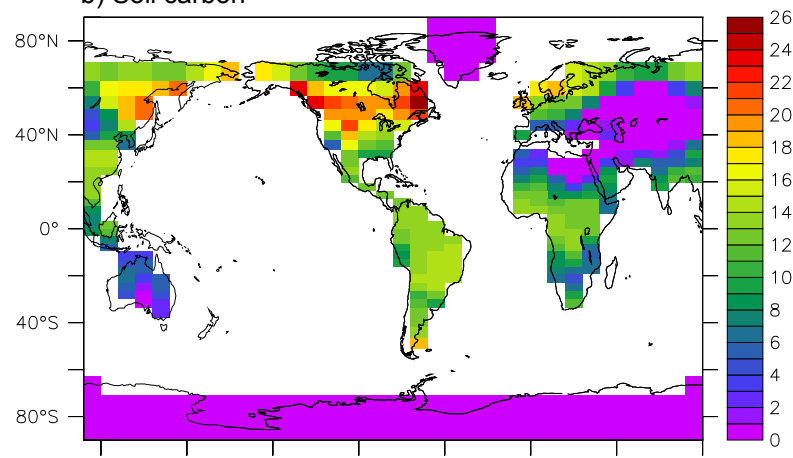

c) Soil carbon $\Delta^{14} \mathrm{C}$ (permil)

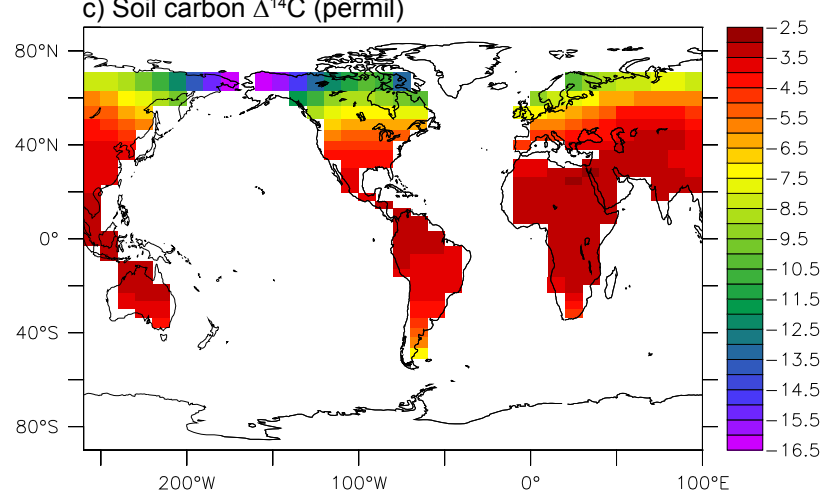

Fig. 12. Simulated annual mean terrestrial biosphere results from MESMO 2E: (a) vegetation carbon stock; (b) soil carbon stock; and (c) soil carbon $\Delta^{14} \mathrm{C}$.

elevated $\mathrm{Si}$ : N uptake ratio in the Southern Ocean and the far North Pacific, $\mathrm{Si}(\mathrm{OH})_{4}$ depletion in the Southern Ocean, and most importantly the export of $\mathrm{Si}(\mathrm{OH})_{4}$ depletion to the rest of the world ocean via some form of intermediate and possibly surface waters. These features make MESMO 2 wellequipped for future investigation of climate-carbon feedbacks involving diatoms, which have received much recent attention, especially in the paleoclimate context.
Acknowledgements. Model development efforts were supported at the University of Minnesota by the McKnight Land Grant Professorship to KM. Efforts by KM elsewhere during sabbatical were supported by visiting fellowships from the University of Tokyo, University of Tasmania, and University of New South Wales. AH and HJW were supported by a summer REU internship programme at the University of Minnesota, made possible by grants from the US National Science Foundation (EAR1004258, 1062775). Numerical computation was carried out using resources at the University of Minnesota Supercomputing Institute.

Edited by: A. Ridgwell

\section{References}

Annan, J. D. and Hargreaves, J. C.: Efficient identification of ocean thermodynamics in a physical/biogeochemical ocean model with an iterative Importance Sampling method, Ocean Model., 32, 205-215, 2010.

Antonov, J. I., Seidov, D., Boyer, T. P., Locarnini, R. A., Mishonov, A. V., Garcia, H. E., Baranova, O. K., Zweng, M. M., and Johnson, D. R.: World Ocean Atlas 2009, Volume 2: Salinity. 69, U.S. Government Printing Office, Washington, 2010.

Archer, D., Eby, M., Brovkin, V., Ridgwell, A., Cao, L., Mikolajewicz, U., Caldeira, K., Matsumoto, K., Munhoven, G., Montenegro, A., and Tokos, K.: Atmospheric lifetime of fossil fuel carbon dioxide, Ann. Rev. Earth Planet. Sci., 37, 117-134, 2009.

Archer, D. and Johnson, K.: A model of the iron cycle in the ocean, Global Biogeochem. Cy., 14, 269-279, 2000.

Armstrong, R., Lee, C., Hedges, J., Honjo, S., and Wakeham, S. G.: A new, mechanistic model for organic carbon fluxes in the ocean based on the quantitative association of POC with mineral ballasts, Deep Sea Res., Part II, 49, 219-236, 2002.

Baker, A. and Jickells, T.: Mineral particle size as a control on aerosol iron solubility, Geophys. Res. Lett., 33, L17608, doi:10.1029/2006GL026557, 2006.

Batjes, N. H.: A homogenized soil data file for global environmental research: A subset of FAO, ISRIC and NRCS profiles (Version 1.0), International Soil Reference and Information Centre, Wageningen, The Netherlands, 1995.

Boyd, P. and Ellwood, M. J.: The biogeochemical cycle of iron in the ocean, Nat. Geosci., 3, 675-682, doi:10.1038/ngeo0964, 2010.

Brzezinski, M. A., Pride, C. J., Sigman, D. M., Sarmiento, J. L., Matsumoto, K., Gruber, N., Rau, G. H., and Coale, K. H.: A switch from $\mathrm{Si}(\mathrm{OH})_{4}$ to $\mathrm{NO}_{3}^{-}$depletion in the glacial Southern Ocean, Geophys. Res. Lett., 29, 12, doi:10.1029/2001GL014349, 2002.

Cao, L., Eby, M., Ridgwell, A., Caldeira, K., Archer, D., Ishida, A., Joos, F., Matsumoto, K., Mikolajewicz, U., Mouchet, A., Orr, J. C., Plattner, G.-K., Schlitzer, R., Tokos, K., Totterdell, I., Tschumi, T., Yamanaka, Y., and Yool, A.: The role of ocean transport in the uptake of anthropogenic $\mathrm{CO}_{2}$, Biogeosciences, 6, 375-390, doi:10.5194/bg-6-375-2009, 2009.

Claussen, M., Mysak, L. A., Weaver, A., Crucifix, M., Fichefet, T., Loutre, M. F., Weber, S. L., Alcamo, J., Alexeev, V., A., 
Berger, A., Calov, R., Ganopolski, A., Goosse, H., Lohmann, G., Lunkeit, F., Mokhov, I. I., Petoukhov, V., Stone, P., and Wang, Z.: Earth system models of intermediate complexity: Closing the gap in the spectrum of climate system models, Clim. Dynam., 18, 579-586, 2002.

De La Rocha, C. L., Brzezinksi, M. A., and DeNiro, M. J.: Fractionation of silicon isotopes by marine diatoms during biogenic silica formation, Geochim. Cosmochem. Acta, 61, 5051-5056, 1997.

De La Rocha, C. L., Brzezinski, M. A., DeNiro, M. J., and Shemesh, A.: Silicon-isotope composition of diatoms as an indicator of past oceanic change, Nature, 395, 680-683, 1998.

Doney, S. C., Lindsay, K., Caldeira, K., Campin, J.-M., Drange, H., Dutay, J.-C., Follows, M., Gao, Y., Gnanadesikan, A., Gruber, N., Ishida, A., Joos, F., Madec, G., Maier-Reimer, E., Marshall, J. C., Matear, R. J., Monfray, P., Najjar, R., Orr, J. C., Plattner, G.-K., Sarmiento, J., Schlitzer, R., Slater, R., Swathi, P. S., Totterdell, I. J., Weirig, M.-F., Yamanaka, Y., and Yool, A.: Evaluating global ocean carbon models: The importance of realistic physics, Global Biogeochem. Cy., 18, GB3017, doi:10.1029/2003GB002150, 2004.

Dunne, J., Sarmiento, J., and Gnanadesikan, A.: A synthesis of global particle export from the surface ocean and cycling through the ocean interior and on the seafloor, Global Biogeochem. Cy., 21, GB4006, doi:10.1029/2006GB002907, 2007.

Eby, M., Weaver, A. J., Alexander, K., Zickfeld, K., Abe-Ouchi, A., Cimatoribus, A. A., Crespin, E., Drijfhout, S. S., Edwards, N. R., Eliseev, A. V., Feulner, G., Fichefet, T., Forest, C. E., Goosse, H., Holden, P. B., Joos, F., Kawamiya, M., Kicklighter, D., Kienert, H., Matsumoto, K., Mokhov, I. I., Monier, E., Olsen, S. M., Pedersen, J. O. P., Perrette, M., Philippon-Berthier, G., Ridgwell, A., Schlosser, A., Schneider von Deimling, T., Shaffer, G., Smith, R. S., Spahni, R., Sokolov, A. P., Steinacher, M., Tachiiri, K., Tokos, K., Yoshimori, M., Zeng, N., and Zhao, F.: Historical and idealized climate model experiments: an EMIC intercomparison, Clim. Past Discuss., 8, 4121-4181, doi:10.5194/cpd-84121-2012, 2012.

Edwards, N. R. and Marsh, R.: Uncertainties due to transportparameter sensitivity in an efficient 3-D ocean-climate model, Clim. Dynam., 24, 415-433, 2005.

Ellwood, M. J., Wille, M., and Maher, W.: Glacial silicic acid concentrations in the Southern Ocean, Science, 330, 1088-1091, 2010.

Foster, T. D. and Carmack, E. C.: Frontal zone mixing and Antarctic bottom water formation in the southern Weddell Sea, Deep-Sea Res., 23, 301-317, 1976.

Franck, V. M., Brzezinski, M. A., Coale, K. H., and Nelson, D. M.: Iron and silicic acid concentrations regulate Si uptake north and south of the Polar Frontal Zone in the Pacific sector of the Southern Ocean, Deep Sea Res. Part II, 47, 3315-3338, 2000.

Garcia, H. E., Locarnini, R. A., Boyer, T. P., Antonov, J. I., Zweng, M. M., Baranova, O. K., and Johnson, D. R.: World Ocean Atlas 2009, Volume 4: Nutrients (phosphate, nitrate, silicate), 71, US Government Printing Office, Washington, 2010.

Hall, F. G., Collatz, G. J., Los, S. O., de Colstoun, E. B., and Landis, D.: ISLSCP Initiative II Data Archive, NASA, 2005.

Honeyman, B. D., Balistrieri, L. and Murray, J. D.: Oceanic tracce metal scavenging andthe imporance of particle concentration, Deep Sea Res. Part I, 35, 227-246, 1988.
Horn, M. G., Beucher, C. P., Robinson, R. S., and Brzezinski, M. A.: Southern ocean nitrogen and silicon dynamics during the last deglaciation, Earth Planet. Sci. Lett., 310, 334-339, 2011.

Houghton, J. T., Ding, Y., Griggs, D. J., Noguer, M., van der Linden, P. J., and Xiaosu, D.: Climate Change 2001 - The Scientific Basis: Contribution of Working Group I to the Third Assessment Report of the Intergovernmental Panel on Climate Change, Cambridge University Press, Cambridge, 944 pp., 2001.

Hutchins, D. A. and Bruland, K. W.: Iron-limited diatom growth and Si:N uptake ratios in coastal upwelling regime, Nature, 393, 561-564, 1998.

Johnson, K. S., Gordon, R. M., and Coale, K. H.: What controls dissolved iron concentrations in the world ocean?, Marine Chem. 57, 137-161, 1997.

Jones, P. D., New, M., Parker, D. E., Martin, S., and Rigor, I. G.: Surface air temperature and its changes over the past 150 years, Rev. Geophys., 37, 173-199, 1999.

Joos, F., Roth, R., Fuglestvedt, J. S., Peters, G. P., Enting, I. G., von Bloh, W., Brovkin, V., Burke, E. J., Eby, M., Edwards, N. R., Friedrich, T., Frölicher, T. L., Halloran, P. R., Holden, P. B., Jones, C., Kleinen, T., Mackenzie, F. T., Matsumoto, K., Meinshausen, M., Plattner, G.-K., Reisinger, A., Segschneider, J., Shaffer, G., Steinacher, M., Strassmann, K., Tanaka, K., Timmermann, A., and Weaver, A. J.: Carbon dioxide and climate impulse response functions for the computation of greenhouse gas metrics: a multi-model analysis, Atmos. Chem. Phys., 13, 2793 2825, doi:10.5194/acp-13-2793-2013, 2013.

Josey, S. A., Kent, C., and Taylor, P. K.: Wind stress forcing of the ocean in the SOC Climatology: Comparisons with the NCEPNCAR, ECMWF, UWM/COADS, and Hellerman and Rosenstein datasets, J. Phys. Oceanogr., 32, 1993-2019, 2002.

Josey, S. A., Kent, E. C., and Taylor, P. K.: Report 6: The Southampton Oceanography Centre (SOC) ocean-atmosphere heat, momentum and freshwater flux atlas, Southampton Oceanography Centre, Southampton, 1998.

Kalnay, E., Kanamitsu, M., Kistler, R., Collins, W., Deaven, D., Gandin, L., Iredell, M., Saha, S., White, G., Woollen, J., Zhu, Y., Chelliah, M., Ebisuzaki, W., Higgins, W., Janowiak, J., Mo, K. C., Ropelewski, C., Wang, J., Leetmaa, A., Reynolds, R., Jenne, R., and Joseph, D.: The NCEP/NCAR 40-year reanalysis project, B. Am. Meterol. Soc., 77, 437-471, 1996.

Key, R., Kozyr, A., Sabine, C., Lee, K., Wannikhof, R., Bullister, J. L., Feeley, R. A., Millero, F., Mordy, C., and Peng, T.-H.: A global ocean carbon climatology: Results from GLODAP, Global Biogeochem. Cy., 18, GB4031, doi:10.1029/2004GB002247, 2004.

Lee, S., Chiang, J., Matsumoto, K., and Tokos, K.: Southern Ocean wind response to North Atlantic cooling and the rise in atmospheric $\mathrm{CO}_{2}$ : Modeling perspective and paleoceanographic implications, Paleoceanography, 26, PA1214, doi:10.1029/2010PA002004, 2011.

Lenton, T. M., Williamson, M. S., Edwards, N. R., Marsh, R., Price, A. R., Ridgwell, A., Shepherd, J. G., and Team, T. G.: Millenial timescale carbon cycle and climate change in an efficient Earth system model, Clim. Dynam., 26, 687-711, doi:10.1007/s00382006-0109-9, 2006.

Locarnini, R. A., Mishonov, A. V., Antonov, J. I., Boyer, T. P., Garcia, H. E., Baranova, O. K., Zweng, M. M., and Johnson, D. R.: World Ocean Atlas 2009, Volume 1: Temperature, 68, US 
Government Printing Office, Washington, 2010.

Mahowald, N., Kohfeld, K. E., Hansson, M., Balkanski, Y., Harrison, S., Prentice, I. C., Schulz, M. and Rhode, H.: Dust sources and deposition during the last glacial maximum and current climate: A comparison of model results with paleodata from ice cores and marine sediments, J. Geophys. Res., 104, 1589515916, 1999.

Marsh, R., Miller, S. A., Yool, A., and Edwards, N. R.: Incorporation of the C-GOLDSTEIN efficient climate model into the GENIE framework: "eb_go_gs" configurations of GENIE, Geosci. Model Dev., 4, 957-992, doi:10.5194/gmd-4-957-2011, 2011.

Matsumoto, K. and McNeil, B. I.: Decoupled response of ocean acidification to variations in climate sensitivity, J. Climate, 26, 1764-1771, doi:10.1175/JCLI-D-12-00290.1, 2013.

Matsumoto, K. and Sarmiento, J. L.: A corollary to the silicic acid leakage hypothesis, Paleoceanography, 23, PA2203, doi:10.1029/2007PA001515, 2008.

Matsumoto, K., Sarmiento, J. L., and Brzezinski, M. A.: Silicic acid leakage from the Southern Ocean: A possible explanation for glacial atmospheric $\mathrm{pCO}_{2}$, Global Biogeochem. Cy., 16, 3, doi:10.1029/2001GB001442, 2002.

Matsumoto, K., Sarmiento, J. L., Key, R. M., Aumont, O., Bullister, J. L., Caldeira, K., Campin, J.-M., Doney, S. C., Drange, H., Dutay, J.-C., Follows, M., Gao, Y., Gnanadesikan, A., Gruber, N., Ishida, A., Joos, F., Lindsay, K., Maier-Reimer, E., Marshall, J. C., Matear, R. J., Monfray, P., Mouchet, A., Najjar, R., Plattner, G.-K., Schlitzer, R., Slater, R., Swathi, P. S., Totterdell, I. J., Weirig, M.-F., Yamanaka, Y., Yool, A., and Orr, J. C.: Evaluation of ocean carbon cycle models with data-based metrics, Geophys. Res. Lett., 31, L07303, doi:10.1029/2003GL018970, 2004.

Matsumoto, K., Tokos, K., Chikamoto, M. O., and Ridgwell, A.: Characterizing postindustrial changes in the natural ocean carbon cycle in an Earth system model, Tellus, 62B, 296-313, 2010.

Matsumoto, K., Tokos, K. S., Price, A. R., and Cox, S. J.: First description of the Minnesota Earth System Model for Ocean biogeochemistry (MESMO 1.0), Geosci. Model Dev., 1, 1-15, doi:10.5194/gmd-1-1-2008, 2008.

Matsumoto, K. and Yokoyama, Y.: Atmospheric D14C reduction in simulations of Atlantic overturning circulation shutdown, Global Biogeochem. Cy., 27, 1-9, doi:10.1002/gbc.20035, 2013.

Moore, J. K., Doney, S., Glover, D. M., and Fung, I. Y.: Iron cycling and nutrient-limitation patterns in surface waters of the World Ocean, Deep Sea Res. Part II, 49, 463-507, 2002.

O'Leary, M. H.: Carbon isotopes in photosynthesis, BioScience, 38, 328-336, 1988.

Olson, J. S., Watts, J. A., and Allison, L. J.: Major world ecosystem complexes ranked by carbon in live vegetation. NDP-017, Carbon Dioxide Information Analysis, Oak Ridge National Laboratory, Oak Ridge, Tenessee, 1985.

Olson, J. S., Watts, V. A., and Allison, L. J.: Carbon in live vegetation of major world ecosystems, ORNL-5862, Oak Ridge National Lab., Oak Ridge, Tenn., 1983.

Parekh, P., Follows, M., and Boyle, E.: Decoupling of iron and phosphate in the global ocean, Global Biogeochem. Cy., 19, GB2020, doi:10.1029/2004GB002280, 2005.

Reynolds, B. C.: Modeling the modern marine $\delta^{30} \mathrm{Si}$ distribution, Global Biogeochem. Cy., 23, GB2015, doi:10.1029/2008GB003266, 2009.
Ridgwell, A. J.: Glacial-interglacial perturbations in the global carbon cycle, PhD Thesis, University of East Anglia, Norwich, 134 pp., 2001.

Ridgwell, A. J., Watson, A. J., and Archer, D. E.: Modeling the response of the oceanic Si inventory to perturbation, and consequences for atmospheric $\mathrm{CO}_{2}$, Global Biogeochem. Cy., 16, 4, doi:10.1029/2002GB001877, 2002.

Riebesell, U., Wolf-Gladrow, D. A., and Smetacek, V.: Carbon dioxide limitation of marine phytoplankton growth rates, Nature, 361, 249-251, 1993.

Sabine, C. L., Feeley, R. A., Gruber, N., Key, R. M., Lee, K., Bullister, J. L., Wanninkhof, R., Wong, C. S., Wallace, D. W. R., Tilbrook, B., Millero, F. J., Peng, T.-H., Kozyr, A., Ono, T., and Rios, A. F.: The oceanic sink for anthropogenic $\mathrm{CO}_{2}$, Science, 305, 367-371, 2004.

Sarmiento, J. L. and Gruber, N.: Ocean Biogeochemical Dynamics. Princeton University Press, Princeton, 503 pp., 2006.

Sarmiento, J. L., Gruber, N., Brzezinski, M. A., and Dunne, J. P.: High-latitude controls of thermocline nutrients and low latitude biological productivity, Nature, 427, 56-60, 2004.

Souza, G. F. D., Reynolds, B. C., Rickli, J., Frank, M., Saito, M. A., Gerringa, L. J. A., and Bourdon, B.: Southern Ocean control of silicon stable isotope distribution in the Atlantic Ocean, Global Biogeochem. Cy., 26, GE2035, doi:10.1029/2011GB004141, 2012.

Sun, X. and Matsumoto, K.: Effects of sea ice on atmospheric pCO2: A revised view and implications for glacial and future climates, J. Geophys. Res., 115, G02015, doi:10.1029/2009JG001023, 2010.

Sunda, W. G. and Huntsman, S. A.: Iron uptake and growth limitation in oceanic and coastal phytoplankton, Marine Chem., 50, 189-206, 1995.

Takeda, S.: Influence of iron availability of nutrient consumption ratio of diatoms in oceanic waters, Nature, 393, 774-777, 1998.

Trenberth, K. E., Olson, J., and Large, W.: A global ocean wind stress climatology based on ECMWF analyses, Tech. Rep. NCAR/TN-338+STR, National Center for Atmospheric Research, Boulder, 1989.

Ushie, H. and Matsumoto, K.: The role of shelf nutrients on glacialinterglacial $\mathrm{CO}_{2}$ : A negative feedback, Global Biogeochem. Cy., 26, GB2039, doi:10.1029/2011GB004147, 2012.

Weaver, A., Sedlacek, J., Eby, M., Alexander, K., Crespin, E., Fichefet, T., Philippon-Berthier, G., Joos, F., Kawamiya, M., Matsumoto, K., Steinacher, M., Tachiiri, K., Tokos, K., Yoshimori, M. and Zickfeld, K.: Stability of the Atlantic meridional overturning circulation: A model intercomparison, Geophys. Res. Lett., 39, L20709, doi:10.1029/2012GL053763, 2012.

Willey, D. A., Fine, R. A., Sonnerup, R., Bullister, J. L., Smethie, M. W., and Warner, M. J.: Global oceanic chlorofluorocarbon inventory, Geophys. Res. Lett., 31, L01303, doi:10.1029/2003GL018816, 2004.

Williamson, M. S., Lenton, T. M., Shepherd, J. G., and Edwards, N. R.: An efficient numerical terrestrial scheme (ENTS) for Earth system modeling, Ecol. Model., 198, 362-374, 2006. 
Wischmeyer, A. G., De La Rocha, C. L., Maier-Rainer, E., and Wolf-Gladrow, D.: Control mechanisms for oceanic distribution of silicon isotopes, Global Biogeochem. Cy., 17, 3, doi:10.1029/2002GB002022, 2003.
Zickfeld, K., Eby, M., Alexander, K., Weaver, A. J., Crespin, E., Fichefet, T., Goosse, H., Philippon-Berthier, G., Edwards, N. R., Holden, P. B., Eliseev, A. V., Mokhov, I., Feulner, G., Kienert, H., Perrette, M., Forest, C. E., Friedlingstein, P., Joos, F., Spahni, R., Steinacher, M., Kawamiya, M., Tachiiri, K., Kicklighter, D., Monier, E., Schlosser, A., Sokolov, A., Matsumoto, K., Tokos, K. S., Olsen, S. M., Pedersen, J. O. P., Ridgwell, A., Shaffer, G., Yoshimori, M., Zeng, N., and Zhao, F.: Long-term climate change commitment and reversibility: An EMIC intercomparison, J. Climate, doi:10.1175/JCLI-D-12-00584.1, 2012. 